\title{
Thomasine Metaphysics of the Image and Its Platonist Background
}

Chapters 2 and 3 of this book reflected on the Thomasine outlook on the phenomenal realm. As I have pointed out, not only does the Gospel of Thomas share with the Middle Platonists a fundamentally negative attitude towards the human body, but also, unlike the Middle Platonists, projects this negative attitude onto the body of the world. In chapters 4 to 7 , I discussed the Platonist impact on the Thomasine views on divinity - namely, the notions of oneness, stability, immutability, indivisibility, and freedom from anger. As I have noted, these notions apply not only to ultimate reality, but also to human perfection, since the qualities of the ideal human often reflect the divine ones.

In this chapter, I discuss the notion of the image according to sayings 22, 5 , 83 , and 84 . The Thomasine metaphysics of the image is, in a way, a territory where the phenomenal and the transcendent realms (discussed in the previous chapters) converge. On the one hand, the term for "image" in these sayings, $\varepsilon i x \omega \dot{\omega} v$, is polysemantic and may be applied to both mundane and divine objects. On the other hand, the metaphysics of the image in the Gospel of Thomas is, as I will argue, an integral part of the Thomasine salvation history: it explains the present-day misery of our worldly existence and informs us about our future reunification with the godhead. In order to attain insight into the Thomasine metaphysics of the image, it is necessary to recognize its indebtedness to the Platonist tradition.

I have already touched upon the topic of Thomasine images in previous chapters: chapter 4 discusses the allusions to Genesis in Gos. Thom. 22:6, and chapter 5 analyzes the meaning of ToY21к0N in Gos. Thom. 50:1. These findings, however, are insufficient for the reconstruction of the Thomasine metaphysics of the image, since saying 83 , by far the most puzzling saying that deals with images, has been left out of the discussion. It is now time to fill this gap.

Thus, I begin this chapter with a discussion of the text of saying 83 , its Platonist background, and its meaning. Then, I turn to other sayings that deal with images (i.e., Gos. Thom. 22, 50, and 84), and offer a reconstruction of the metaphysics that they presuppose. 


\section{The Text of Gos. Thom. 83}

Bentley Layton's edition and Thomas O. Lambdin's English translation of the Coptic text present saying 83 as follows. ${ }^{1}$

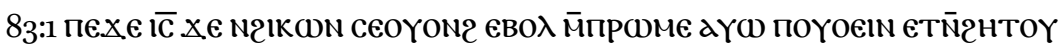

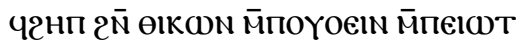

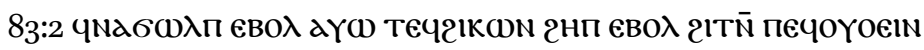

83:1 Jesus said, "The images are manifest to man, but the light in them remains concealed in the image of the light of the father.

83:2 He will become manifest, but his image will remain concealed by his light."

The meaning of this text is obscure. As Peter Nagel puts it, saying 83 "ist ebenso tiefgründig wie unverständlich." ${ }^{2}$ Scholars who have made an attempt to ascertain the meaning of the saying have faced insurmountable difficulties. Perhaps the most remarkable attempt to make sense of the Coptic text as it stands was made by April D. DeConick. According to her, the visible images described in Gos. Thom. 83:1 correspond to our material bodies, while the image that conceals their light corresponds to God's glory, the כָּב of Jewish mysticism, "surrounded by radiant light." 3 Thus, Gos. Thom. 83:1 maintains that "the human's image or body is visible while the light within the human body is hidden

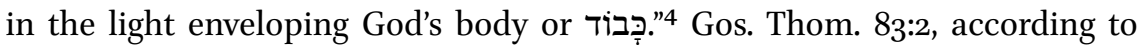
DeConick, deals with the mystic who will see God's כָָָּ "hidden by a screen of light." ${ }^{5}$

Despite its ingenuity, DeConick's exegesis of saying 83 has a serious weakness. She interprets the text of Gos. Thom. 83:1 as if it read "the light of the image of father." Gos. Thom. 83:1 in fact deals with the image of the light, not with the image of God (= God's דָָּ, according to DeConick). The light concealed within human beings is hidden in the image of God's light, not in the light that emanates from God's image. Thus, DeConick's interpretation of saying 83

1 The versification follows Kloppenborg et al. 1990, 148-149.

2 Nagel 2004, 251.

3 DeConick 1996, 102.

4 Ibid., 115 .

5 DeConick 2007, 248. 
demonstrates how difficult the phrase "the image of the light of the father" is to interpret and how eager scholars are to gloss over it.

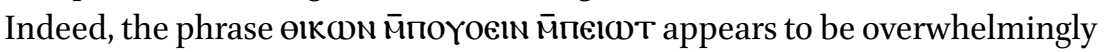
problematic and unparalleled in ancient sources. It is tempting, therefore, to approach the saying from a different perspective. It is likely that the solution to the problem is not exegetical, but text-critical. In other words, it is possible that the text is incomprehensible, because it is corrupt. I subscribe to the opinion expressed by the Berliner Arbeitskreis that the preposition $\bar{M}$ - before noүoein is a scribal error. ${ }^{6}$ The English translation of the emended text is as follows:

83:1 Jesus said, "The images are manifest to man and the light in them is concealed in the image.

83:2 The light of the father will become manifest and his image will be concealed by his light." ${ }^{7}$

There are two reasons why this emendation should be accepted. One has to do with the structure of the saying, the other with its content. First, the emended text boasts a much more refined form. While the text of the saying as preserved by NHC II has no parallelism, the emended text has an elaborate chiastic structure: image—light—image / light—image—light:

83:1 $\mathrm{A}-\mathrm{B}-\mathrm{A} \quad$ the images are manifest; the light is concealed in the image $83: 2 \quad \mathrm{~B}-\mathrm{A}-\mathrm{B} \quad$ the light will be manifest; the image will be concealed by the light

It does not seem probable that a saying that originally had no parallel structure would attain such a structure by omitting a single letter; it is much more likely that the original structure of the saying was chiastic and that, at some point, a Coptic copyist made a mistake that distorted the parallel structure. ${ }^{8}$

What makes it even more likely that the original structure of saying 83 was chiastic is the fact that the Gospel of Thomas clearly has a soft spot for this literary device. There are at least nine other instances of chiastically structured

6 See Bethge 1998, 48-49.

7 The conjunction aY $\omega$ in Gos. Thom. 83:1 and 83:2 seems to render a "consecutive" $x \alpha$, not an "adversative" one; see Blass, Debrunner, and Rehkopf 1990, 367 (§ 442, 1-2).

8 For another instance of the copyist's mistake in the Coptic text of the Gospel of Thomas, see the discussion of the text of Gos. Thom. 6:4 in chapter 1. 
Thomasine sayings: Gos. Thom. $4: 2,{ }^{9} 5,{ }^{10} 7,{ }^{11} 24: 3,28: 1,^{12} 36: 1,{ }^{13} 43: 3,56$ and 80 (a doublet), ${ }^{14}$ and $112 .{ }^{15}$

$\begin{array}{lll}4: 2 \mathrm{a} & \mathrm{A}-\mathrm{B} & \text { the first will be last } \\ 4: 2 \mathrm{~b} & \mathrm{~B}-\mathrm{A} & \text { the last will be first }\end{array}$

5:1 $\quad$ B - A $\quad$ come to know the manifest and you will know the hidden

5:2 $\quad A-B \quad$ for there is nothing hidden which will not become manifest

7:1a $\quad A-B \quad$ the lion is eaten by the man

7:1b $\quad \mathrm{A}-\mathrm{B} \quad$ the lion becomes a man

$7: 2 \mathrm{a} \quad \mathrm{B}-\mathrm{A} \quad$ the man is eaten by the lion

$7: 2 \mathrm{~b} \quad \mathrm{~B}-\mathrm{A} \quad$ the man becomes a lion

24:3a $\quad A-B \quad$ if there is light, then it shines

24:3b $\quad B^{\prime}-A^{\prime} \quad$ if it does not shine, then there is no light

28:1a $\quad A-B \quad$ I stood in the middle of the world

28:1b $\quad$ B-A In flesh I appeared to them

36:1a $\quad \mathrm{A}-\mathrm{B} \quad$ worry not from morning to evening

$36: 1 \mathrm{~b} \quad \mathrm{~B}-\mathrm{A} \quad$ nor from evening to morning

43:3b $\quad$ A-B they love the tree; they hate the fruit

43:3C B-A they love the fruit; they hate the tree

56:1/80:1 A-B he who has come to know the world has found a corpse/body

56:2/80:2 B-A of him who has found a corpse/body, the world is not worthy

9 As I argue in chapter 4, the original wording of this saying is preserved in P.Oxy. 4.654; the omission of Gos. Thom. 4:2b in the Coptic text is secondary.

10 As I argue in appendix 2, the original wording of this saying is preserved in the Coptic text; Gos. Thom. 5:3, attested by P.Oxy. 4.654, is a later addition.

11 For a reconstruction of the original text of this saying, see chapter 7.

12 For a discussion of Gos. Thom. 24:3 and 28:1, see chapter 5 .

13 Gos. Thom. 36:1 is attested in two textual witnesses, NHC II and P.Oxy. 4.655; the subsequent verses, Gos. Thom. 36:2-4, are attested only in P.Oxy. 4.655 .

14 For a discussion of these two sayings, see chapter 2.

15 For a discussion of this saying, see chapter 3. 
$\begin{array}{lll}\text { 112:1 } & \text { A- } & \text { flesh depends upon the soul } \\ \text { 112:2 } & \text { B-A } & \text { the soul depends upon flesh }\end{array}$

My second argument in support of the emendation suggested by the Berliner Arbeitskreis is concerned with the content of saying 83. As the following discussion of the background and meaning of the saying will demonstrate, the improved text clearly makes much more sense than the one attested by NHC II. ${ }^{16}$

It seems reasonable to make an inventory of the constituting elements of the saying before proceeding to a discussion of its background and meaning. Gos. Thom. 83 is a chiasm and thus comprises two opposing statements. The first statement deals with what is; the second, with what will be. The saying also opposes two types of images, the mundane with the divine. They differ with regard to their visibility: the divine images are hidden, the mundane images manifest. Moreover, there is an intimate relationship between images and light, and there is a principle that describes their relations: if the images are manifest, then the light is hidden, and vice versa. All these elements of the saying can be represented by the following diagram:

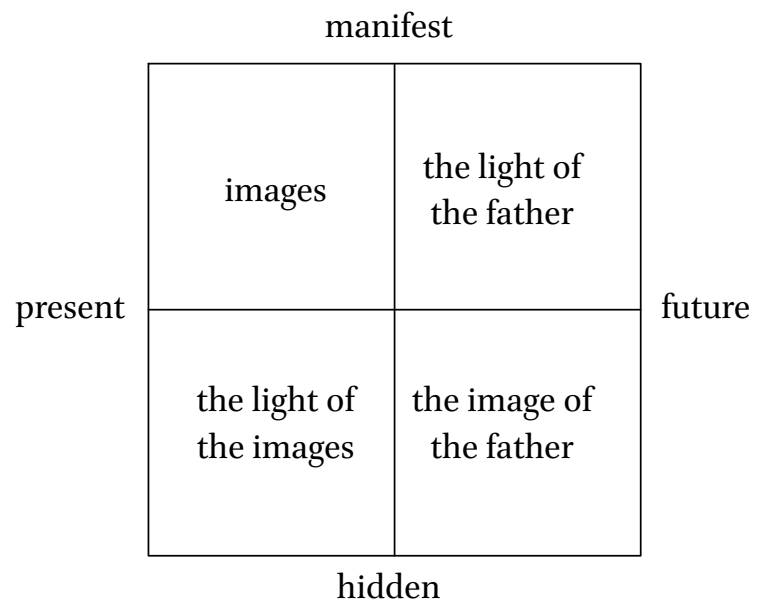

Thus, to offer a thorough exegesis of the saying, an interpreter would need to answer a long list of questions. What are these visible images? Why is there light in them? Why will the light of the father become manifest? What is the image of

16 Pace Popkes 2008, 419, who maintains that "this reading does not clarify the content matter of the text." 
the father? How is it that it will be concealed by the light? I will give my answers to these questions as soon as I have discussed the Platonist background of the saying.

\section{The Two Types of Images in Middle Platonism}

It is quite remarkable that saying 83 contrasts the images that are visible and mundane with the images that are invisible and divine. The only intellectual tradition contemporary with the Gospel of Thomas that was aware of these two different types of images was Middle Platonism. It is thus very likely that Thomasine metaphysics of images is indebted to the Platonist tradition.

In this section, I discuss the Platonist background of Gos. Thom. 83. I argue that the notion of image in Gos. Thom. 83:1 comes from Plato's dialogues and that NqIKONN (" Eixóves) here are the objects present in the sensible world. I also argue that the notion of the image of the father (Gos. Thom. 83:2), to which these mundane images are contrasted, can be traced back to Middle Platonist speculations about paradigmatic images.

\section{$1 \quad$ The Mundane Images}

As Friedrich-Wilhelm Eltester puts it, "Plato kann die Ideen als Vorbilder ( $\pi \alpha \rho \alpha-$

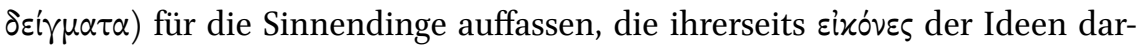
stellen."17 It is certainly true that Plato in his dialogues often maintains that

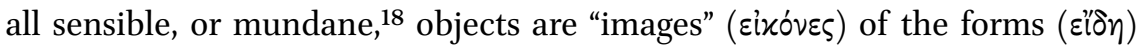
which serve as their models $(\pi \alpha p \alpha \delta \varepsilon i \gamma \mu \alpha \tau \alpha) .{ }^{19}$ It would not, however, do justice

17 Eltester 1958, 27.

18 The term "mundane" appears to be more accurate than "sensible." For instance, a just law would probably qualify as an image of justice, but it most certainly would not qualify as a sensible object.

19 Sensible objects can also be called $\varepsilon^{\prime} \delta \omega \lambda \alpha$ ("images"), $\mu \iota \eta \dot{\eta} \mu \alpha \tau \alpha$ ("imitations"), $\delta \mu o เ \omega \mu \alpha \tau \alpha$ ("likenesses"), and $\varphi \alpha \nu \tau \alpha ́ \sigma \mu \alpha \tau \alpha$ ("apparitions"). On Plato's image terminology, see Patterson 1984, 30-31. It is worth noting that, as Cornford 1935, 198, points out, "Plato is never rigid in his use of terms." Thus, although the terms $\varepsilon i x \omega \nu v$ and $\varepsilon \delta^{\prime} \delta \omega \lambda$ ov are often used interchangeably, in Soph. 235b-236c, Plato makes an exception. Here, he distinguishes between

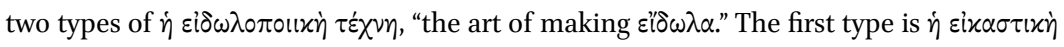

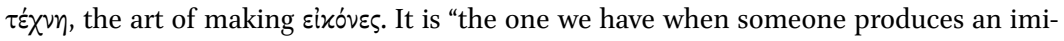
tation $(\mu i \mu \eta \mu \alpha)$ by keeping to the proportions of length, breadth, and depth of his model ( $\pi \alpha \rho \alpha \delta \varepsilon \varepsilon \gamma \mu \alpha)$, and also by keeping to the appropriate colors of its parts" (trans. N.P. White). The second type is $\dot{\eta} \varphi \alpha \nu \tau \alpha \sigma \tau i x \dot{\eta} \tau \dot{\varepsilon} \chi \nu \eta$, "the art of making $\varphi \alpha \nu \tau \alpha \dot{\alpha} \sigma \alpha \tau \alpha$." It is the sort we 
to Plato to reduce the opposition of an image with its model to the relationship between the sensible and noetic realms, since, as we will see, it is possible for a sensible object to be an image of another sensible object. Thus, it would be perhaps more accurate to argue that $\varepsilon i x \omega \dot{v}$ is one of the terms Plato applies to sensible objects in order emphasize the fact that they are not independent and, therefore, do not truly exist. In what follows, I would like to list the main features of Plato's understanding of $\varepsilon i x \omega \dot{v}$ :

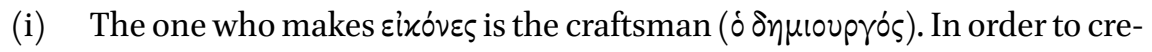
ate an $\varepsilon i x \omega \dot{\omega} v$, craftsmen have to look ( $\beta \lambda \varepsilon \dot{\varepsilon} \pi \varepsilon v)$ at a model. If a craftsman

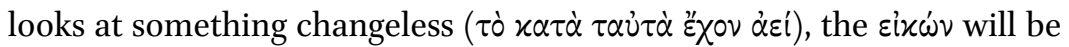
beautiful, but if he looks at something that came into being ( $\gamma \varepsilon \gamma o v o ́ s)$, it will not be (Tim. 28a-b).

(ii) Images differ with regard to their faithfulness to their models. For instance, when Socrates discusses names as eixóveৎ created by a "craftsman

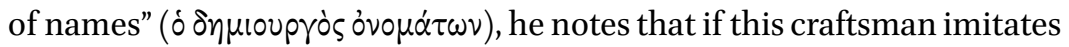
$(\dot{\alpha} \pi \circ \mu \mu \varepsilon \hat{\varepsilon} \sigma \theta \alpha)$ ) the essence of things ( $\dot{\eta} \circ \dot{\sigma} \sigma \dot{\alpha} \alpha \tau \hat{\omega} \nu \pi \rho \alpha \gamma \mu \dot{\alpha} \tau \omega \nu$ ) correctly, that $\varepsilon i x \omega \dot{\omega} v$ will be beautiful. If he fails to do so, it will not be. Accordingly, some names are fashioned beautifully ( $\varkappa \alpha \hat{\omega} \varsigma)$ and some crudely ( $\kappa \alpha \kappa \hat{\omega} \varsigma)$ (Crat. 431c-e).

(iii) Everything we encounter in this world is an image. Even time is a mov-

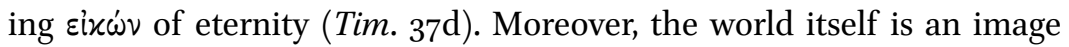
produced by its craftsman according to the eternal model (Tim. 29a-b; cf. 39e). As a perceptible god ( $\theta \varepsilon \dot{s} \varsigma \alpha i \sigma \theta \eta \tau o ́ s)$, it is the image of the intelli-

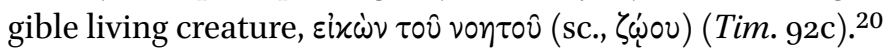

(iv) Images are not duplicates of their models. An exact copy of Cratylus is another Cratylus, not an image of Cratylus (Crat. $432 \mathrm{~b}-\mathrm{c}){ }^{21}$

(v) Every $\varepsilon i x \omega \dot{\omega} v$ is always a transitory apparition of something else (Tim. $5^{2 \mathrm{C}}$; see below, pp. 228-229). For this reason, घixóves do not truly ( $\dot{\lambda} \lambda \eta \hat{\omega} \varsigma)$ exist

have when someone distorts the proportions of his model. It is worth noting that this passage does not distinguish between a "good" and a "bad" type of imitation. Rather, the former type is, as Robinson 1953, 219, puts it, "at best, only less bad" than the latter. Thus, despite its peculiar terminology, this passage is as unfavorable to images as the ones I discuss below.

20 The construction is explained in Taylor 1928, 648. Festugière 1936, 478, argued for "the

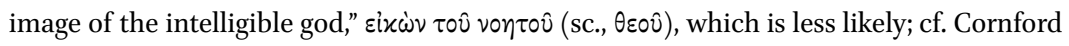
1956, 359.

For an analysis of Plato's train of thought in Crat. 432b-c, see Sedley 2003, 137-138. 


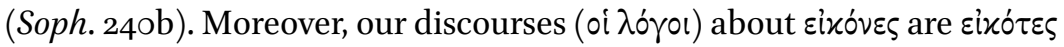
(i.e. not firm, but only probable) (Tim. $29 \mathrm{~b}-\mathrm{c}$ ).

(vi) In this world, we occasionally encounter images of the objects that are

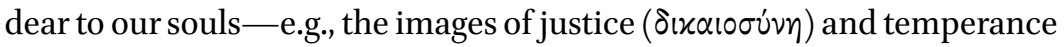

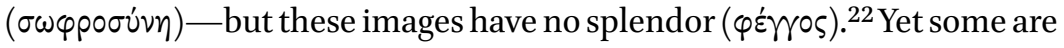

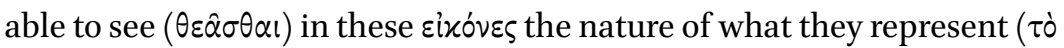

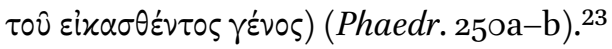

(vii) Images are of no use to the soul that strives to reach the uppermost level of the intelligible reality (Resp. 510b; see below, pp. 229-231).

In what follows, I would like to offer a somewhat more detailed discussion of two of the passages mentioned in this bulleted survey of Plato's metaphysics of $\varepsilon i x \omega^{\prime} v$. First, Tim. 52c certainly deserves to be discussed at greater length. As Edward N. Lee points out, in this passage, "Plato enunciates the suddenly technical, doctrinally concise definition of the being of an image ( $\varepsilon i x(\omega)$ ) as dependent both upon that 'in which' it occurs and that 'of which' it is an image." ${ }^{24}$ This passage belongs to the part of the dialogue wherein Timaeus explains the relation between the form, the image, and the receptacle:

Since even that with an eye to which an image came to be does not belong

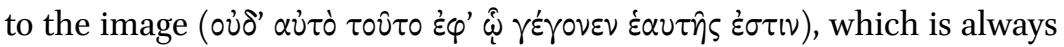

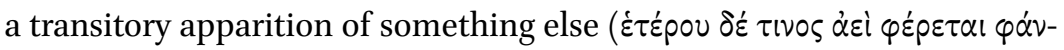
$\tau \alpha \sigma \mu \alpha)$, it stands to reason that the image should therefore come to be

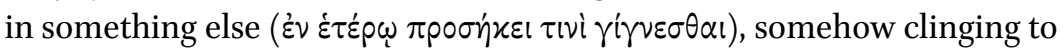
being, or else be nothing at all. ${ }^{25}$

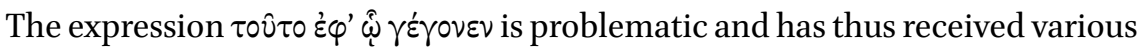
interpretations. ${ }^{26}$ In his very learned and detailed article on this expression, Harold Cherniss suggested that it should be translated as "that which an image signifies," arguing that the point here is

\footnotetext{
22 Later $(250 \mathrm{c}-\mathrm{e})$, Plato points out that beauty ( $\kappa \dot{\alpha} \lambda \mathrm{\lambda} \circ)$ holds an exceptional position and, as Patterson 1984, 28, puts it, provides us "with many distinct visual images."

23 Cf. de Vries 1969, 149.

24 Lee 1966, 347.

25 Tim. 52c, trans. D.J. Zeyl, altered.

26 See Cherniss 1977, 364-375.
} 
that any particular image stands for something, refers to something, means something and that this meaning the image has not independently as its own but only in reference to something else, which is not dependent upon it but of which, as the parallel and complementary clause says, "it is always a transitory apparition." 27

I am, however, inclined to side with Richard Patterson who called this interpretation into question, arguing that the passage is not about an image as a sign of its model, but rather about the "of-ness" of images, ${ }^{28}$ or, as Lee put it, "the internal, continuing, essential relatedness" of an image to its model. ${ }^{29}$

From the fact that images are always of something else, Plato draws an inference that they must also be in something else. ${ }^{30}$ As Richard Patterson puts it, the text stresses "a double dependence" of images, "dependence at once on the model of which it is an image and on the medium in which it must come to be if it is to be anything at all." ${ }^{31}$

The second Platonic passage I would like to examine in this survey is the famous Simile of the Divided Line (Resp. 5o9d-511e). Indeed, a discussion of Plato's sixóves cannot do without mentioning it. According to James Adam, this simile contains "more Platonic teaching than any passage of equal length in Plato's writings, and is of primary and fundamental importance for the interpretation of his philosophy."32 Scholarly publications offering various attempts to understand the simile are almost innumerous. ${ }^{33}$ In what follows, I will not delve into a detailed interpretation of this passage, but rather focus on the significance and various types of eixóves in it.

According to the simile, the two unequal sections of a divided line represent the intelligible and sensible realms. Each of these two sections, in turn, is unequally divided into two subsections, each of which represents a particular type of objects and corresponds to one of the four conditions $(\pi \alpha \theta \dot{\eta} \mu \alpha \tau \alpha)$ of the soul:

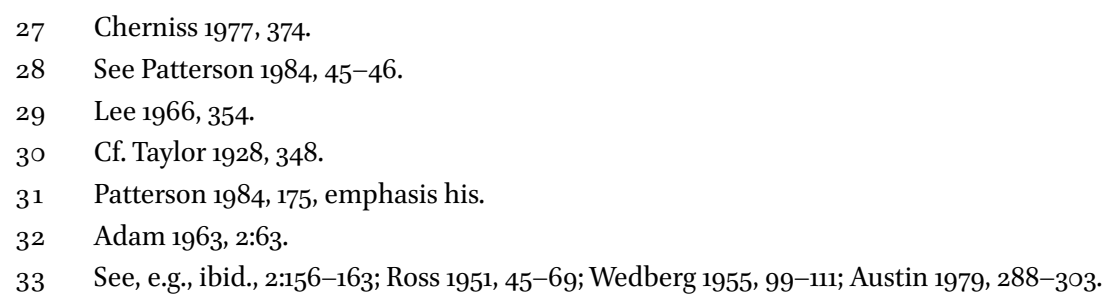




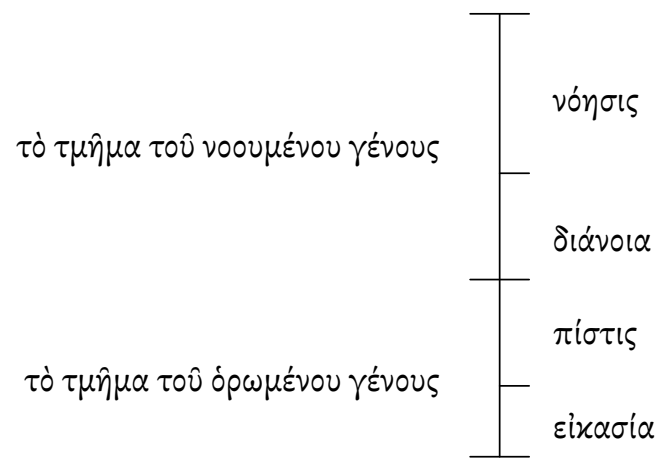

The first subsection of the lower part of the line consists of shadows ( $\sigma$ « $\alpha i)$, reflections $(\varphi \alpha \nu \tau \dot{\alpha} \sigma \mu \alpha \tau \alpha)$, and other objects of this sort which Plato catego-

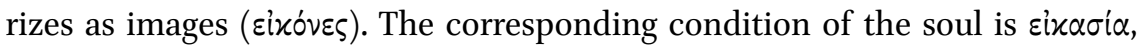
"conjecture" (i.e., grasping the nature of an object by means of its image). ${ }^{34}$ The next subsection of the lower part of the line consists of that which घixóves

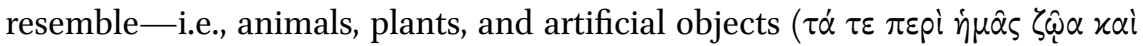

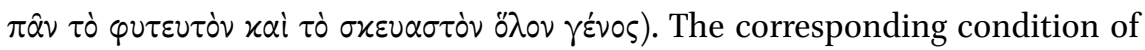
the soul is $\pi i \sigma \tau \iota \varsigma$, "belief."

The first subsection of the upper part of the line includes that aspect of the intelligible reality which is the object of geometry and related sciences. The corresponding condition of the soul is $\delta\left\llcorner\alpha v^{\prime}\llcorner\alpha\right.$, "thought." In order to approach

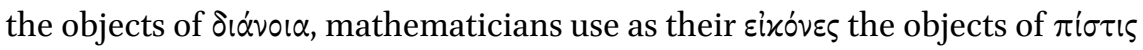

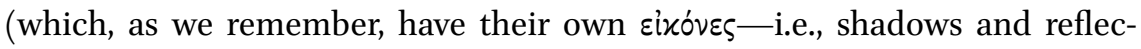
tions). "These figures that they make and draw, which have shadows and images

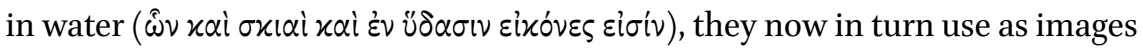

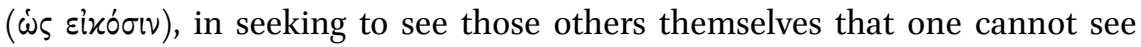

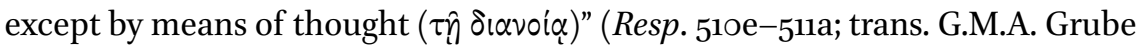
and C.D.C. Reeve, altered).

Finally, the last and uppermost subsection of the line includes that aspect of the intelligible reality which is the object of dialectic and which is clearer and truer ( $\sigma \alpha \varphi \varepsilon$ $\sigma \tau \varepsilon \rho \circ \nu)$ than that of mathematics. The corresponding condition

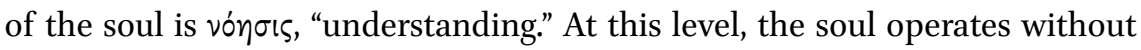

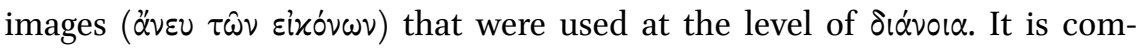
pletely detached from sensible objects and makes its investigation through

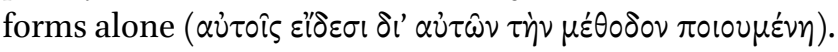


As Anders Wedberg puts it, "it seems that the relation of image to original is part of the very meaning of the relationship which the simile of the line asserts between the various classes of objects." ${ }^{35}$ It also seems that the four conditions of the soul are distinguished by different types of involvement with images. Conjecture operates with the images of the sensible objects, belief with sensible objects themselves; at the level of understanding, however, sensible objects reappear as images. It is only at the level of thought that the soul is by no means involved with images.

The two passages discussed above, Tim. 52c and Resp.509d-511e, are crucial to understanding Plato's eixóves. His attitude towards them is hardly favorable. While the former passage emphasizes the transient nature of images and their lack of independence, the latter describes the ascent to ultimate reality as a gradual detachment from them. Richard Robinson goes as far as to describe the philosophy of Plato as the "condemnation of images":

Plato's whole theoretical philosophy is largely a condemnation of images and a struggle to get away from them. Man, he holds, has the misfortune to be so circumstanced that he inevitably begins life by taking shams for realities. The world revealed by the senses, which engrosses all of us at first, is only a half-real image of true being; and wisdom lies in the progressive substitution of the pure for the adulterated, looking forward to the day when "we shall know through ourselves all that is pure" (Phd. $67 \mathrm{AB})$. In accordance with this view he urges us to abandon the senses and seek knowledge by the soul alone; his insistence that the best knowledge makes no use whatever of sensibles, even as images of the real, is itself a condemnation of images (e.g., $R p \cdot 5^{10-511)}{ }^{36}$

It comes as no surprise, then, that the Middle Platonists inherited Plato's notion

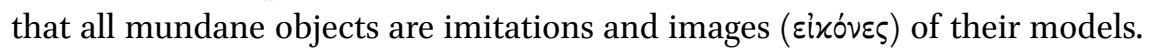
The following passage from Alcinous' handbook illustrates the Middle Platonist use of this notion: ${ }^{37}$

35 Wedberg 1955, 105.

36 Robinson 1953, 220, emphasis his.

37 This passage is strikingly similar to that of Arius Didymus, preserved in Eusebius, Praep. ev.11.23.3-6, and Stobaeus, Anth. 1.12.2a; see the synoptic table in Diels 1879, 447. The usual explanation for this similarity—viz., that Alcinous copied from Arius Didymus (see, e.g., Whittaker 1987, 93-94; Dillon 1993a, 115)—has been questioned by Göransson 1995, 196202, who suggests the inverse scenario-viz., that Arius Didymus copied from Alcinous. Lebedev 2016, 610-613, offers a critique of Göransson's arguments, defending the tradi- 
Since of natural individual objects of sense-perception there must exist

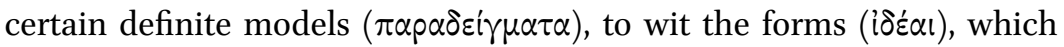
serve as the objects of scientific knowledge and definition (for besides all (individual) men one possesses the concept of Man, and besides all (individual) horses that of Horse, and in general, beside all living things the ungenerated and indestructible form of Living Thing, just as from one seal there derive many impressions, and of one man myriads upon myr-

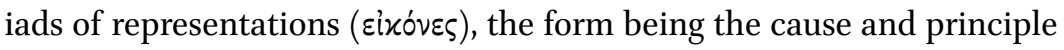
in virtue of which each thing is such as it itself is) - since, then, that is so, it is necessary that the most beautiful of constructions, the world, should have been fashioned by God looking to a form of World, that being the model of our world, which is only copied from it ( $\pi \alpha \rho \alpha \dot{\delta} \varepsilon i \gamma \mu \alpha$ i $\pi \dot{\alpha} p X 0 v \sigma \alpha \nu$

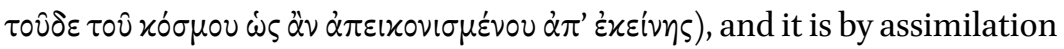
to it that it is fashioned by the creator. ${ }^{38}$

In this passage, Alcinous employs two cognate words, $\varepsilon i x \omega \dot{\omega} \nu$ ("image") and $\dot{\alpha} \pi \varepsilon l-$

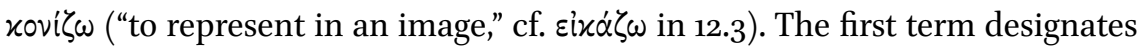
images in the nontechnical sense-i.e., portraits and statues (cf. 9.1). Just as there may be many portraits and statues of one human being, so also may numerous sensible objects derive from a single form. The second term, however, is applied to the world; according to Alcinous, the world is an image of its model (cf. 12.3). By implication, all other sensible objects are also images of their models.

It is now possible to see the relevance of the Platonist metaphysical terminology for the understanding of saying 83 . A natural conclusion a reader of Plato's dialogues might have made would be that every object of the sensible

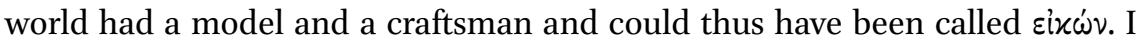
believe that this is the conclusion the author of saying 83 made. The images that are visible to the human being are the objects present in the sensible world.

\section{$2 \quad$ The Paradigmatic Images}

Quite surprisingly, the term sixw่v received a new meaning in Middle Platonism. While in Plato, $\varepsilon i x(\omega) v$ serves as an equivalent of $\mu$ i $\mu \eta \mu \alpha$ ("imitation"), Middle Platonists sometimes use it as an equivalent of $\pi \alpha \alpha_{\alpha} \delta \varepsilon \imath \gamma \mu \alpha$ ("model"). A

tional explanation. My inclination is somewhere between these two positions-viz., that Alcinous and Arius Didymus used the same source (see Dörrie and Baltes 1993, 237). 
model is an image in the sense that it serves as the "blueprint" of a mundane object. Hence, there are paradigmatic images in addition to Plato's mundane ones.

Interestingly, this new usage of the term sixw'v made its way into several accounts of Plato's teaching. One instance occurs in the summary of Platonic doctrine by Pseudo-Origen (Ref. 1.19). ${ }^{39}$ According to this summary, there are three first principles ( $\dot{\alpha} p \chi \alpha \hat{i})$ —viz., God, matter, and the model. ${ }^{40}$ In turn, the

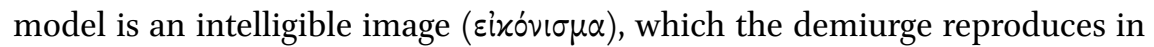
sensible objects:

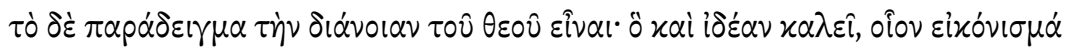

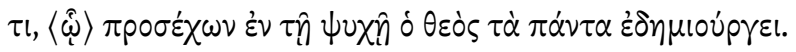

The model is the thought of God; he [i.e., Plato] also calls it "form," a kind of image which God looked at in his soul and created everything. ${ }^{41}$

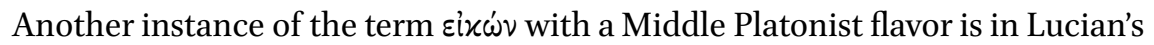
Vitarum auctio, which gives an ironic exposition of Plato's teaching. When a

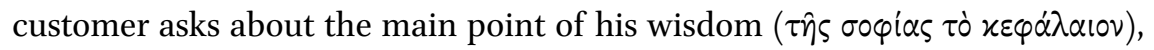
Socrates gives the following answer:

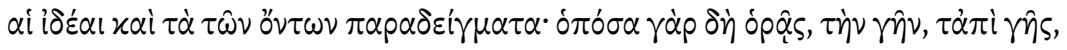

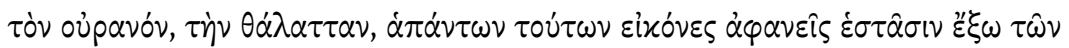
$\ddot{\partial} \lambda \omega \nu$.

The forms and the models of existing things; for of everything you see, the earth, the things on the earth, the sky, the sea, there are invisible images outside the universe. ${ }^{42}$

39 Pseudo-Origen's exposition of Plato's doctrines is based on a Middle Platonist source; cf. Dillon 1996, 410-414.

40 On this traditional Middle Platonist triad of first principles, see, e.g., Tobin 1985, 14-15. As Dörrie 1976, 342, puts it, "Die Drei-Prinzipien-Lehre, wonach Gott, Idee und Materie die Ursachen der Welt sind, ist der Kernsatz des Mittelplatonismus." See also the list of references to the triad in Gersh 1986, 244-246. On $\pi \alpha \rho \alpha \dot{\delta \varepsilon} \gamma \mu \alpha$ in the singular, see the discussion of Pseudo-Timaeus, below (pp. 235-236).

$41 \quad$ Ref. 1.19.2.

42 Vit.auct. 18. 
In her commentary on this passage, Thérèse Beaupère pointed out that, in his Vitarum auctio, Lucian was usually quite faithful to the terminology of the philosophers he was trying to ridicule. Yet the way the term eixóves is used here is clearly inappropriate, since in Plato's dialogues it is employed in the opposite sense. She concludes that Lucian speaks tongue in cheek: the models are pure abstractions and, therefore, "images" that do not truly exist. ${ }^{43}$ As Jacques Bompaire puts it, this is "une plaisanterie désinvolte sur la théorie de Platon." ${ }^{4}$ This suggestion, however, becomes unnecessary if we presuppose that Lucian was familiar with the Middle Platonist use of the term. While the whole dialogue between Socrates and the customer is full of irony, it was probably intended to be seen as a relatively faithful account of Plato's doctrines.

A third instance of such a use of the term is in Galen's Compendium Timaei Platonis written ca. $18 \mathrm{OCE}^{45}$ one of the two extant Middle Platonist epitomes of Plato's Timaeus. ${ }^{46}$ Galen maintains that there are three causes of the world: first, effective cause, 'illah fā'ilah (i.e., the creator, al-khäliq); second, "the image (al-timthăl) according to which he [i.e., the creator] created it [i.e., the world]"; and third, God's generosity, jūd Allāh. ${ }^{47}$ As A.-J. Festugière pointed out, this list of causes is identical to the one Proclus has in his commentary on the Timaeus; according to Proclus, Plato taught that the world had three causes, the demi-

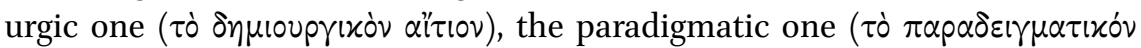

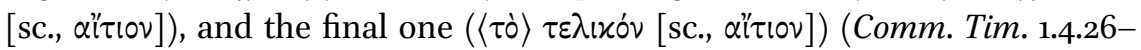

43 See Beaupère 1967, 2:99-100.

44 Bompaire 2008, 91.

45 Walzer 1949, 16.

46 A very short summary of Timaeus is also present in Exp. Plat. 32. It is also plausible that, in al-Fārābī's Falsafat Aflātun ("The Philosophy of Plato"), the summary of Plato's dialogues, including Timaeus, draws upon a lost Middle Platonist source (see Walzer and Rosenthal 1979, xii-xvi; Connelly 2016). On the other hand, De natura mundi et animae by PseudoTimaeus, is, as noted in Baltes 1972, 10, "keine Timaiosepitome im eigentlichen Sinne." All in all, there can be little doubt that, in antiquity, epitomes of this dialogue were, as put in Runia 1986, 55, "in plentiful supply." For instance, we know from Simplicius that Aristotle

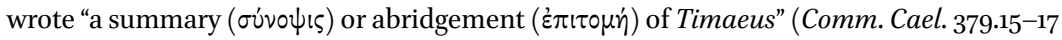
Heiberg; cf. 296.16-18 Heiberg = Aristotle, fr. 206 Rose). This epitome might be identical to

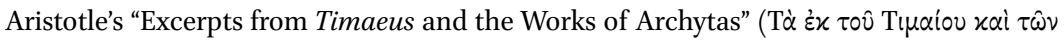

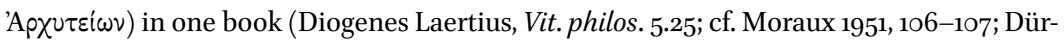
ing 1957, 47). In this case, Aristotle must have seen a connection between the doctrines of Plato's Timaeus and those of Archytas, “doch wohl in der Richtung, daß Platon sich von Archytas habe anregen lassen" (Gigon 1987, 407).

See Walzer and Kraus 1951, 4-5 (Arabic text), 38-40 (Latin translation). 
28 Diehl). Festugière also noted that this interpretation is in fact quite faithful to Plato's own account; one could easily deduce that the demiurgic cause is discussed in Tim. 28a-c; the paradigmatic one, in Tim. 28c-29d; and the final one, in Tim. $29 \mathrm{~d}-3$ oc. ${ }^{48}$

There is, however, an important detail that distinguishes Galen's account from that of Plato. Unlike Plato, Galen does not make any distinction between the model and its image. ${ }^{49}$ In his view, the model is the image (there can be little doubt that timthāl corresponds to sixw'v of the lost Greek original), according to which the world was created. Galen is therefore one of those Middle Platonists who employed the concept of paradigmatic image.

While Galen, in his Compendium, mentions only the paradigmatic image, quite a few Middle Platonists employ the term sixw $v$ in both senses. One of the earliest texts aware of both the mundane images and the paradigmatic ones is De natura mundi et animae, a first-century $\mathrm{BC}$ or first-century $\mathrm{CE}^{50}$ pseudepigraphon written in Doric and ascribed to Timaeus of Locri.

Pseudo-Timaeus is familiar with Plato's use of the term. In Nat. mund. an. 30 , he paraphrases Tim. $37 \mathrm{~d},{ }^{51}$ saying that time is the image of eternity. He goes on to say that time imitates its model, eternity, in the same fashion as the heaven

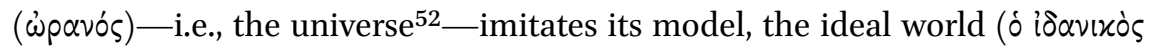

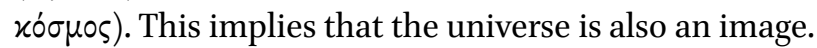

At the same time, Pseudo-Timaeus is one of the first authors to use the term

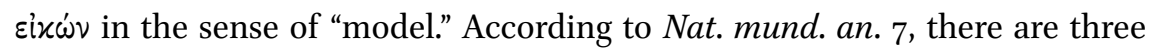

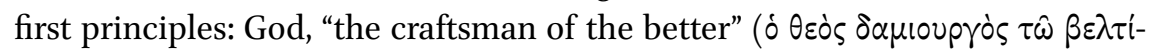
ovo५), matter ( $v \lambda \alpha$ ), and the form (i $i \delta \varepsilon \alpha)$. Interestingly, Pseudo-Timaeus always uses the terms $i \delta \delta \varepsilon \alpha$ and $\varepsilon \hat{\delta} \delta \circ \varsigma$ in the singular. This peculiarity occurs in a number of sources, most importantly in Alcinous (Didasc. 9.1; 10.3; 12.3). ${ }^{53}$ According to Dillon, "the adoption of this curious collective noun is presumably influenced by the presentation of the world of forms as a coherent whole. ${ }^{54}$ In short, the

\footnotetext{
48 See Festugière 1971, 495.

49 Cf. Walzer and Kraus 1951, 39-40.

50 For this date, see Tobin $1985,3-7$.

51 This famous Platonic passage is also paraphrased by Plutarch and Apuleius (see below), Alcinous (Didasc. 14.6), and Diogenes Laertius in his summary of Plato's doctrines (Vit. philos. 3.73). It is also mentioned in Plac. philos. 1.21.2 (see Diels 1879, 318).

52 Cf. Baltes 1972, 49 .

53 See also Plutarch, Quaest. conv. 720a-b; Pseudo-Origen, Ref. 1.19.2 (cited above, p. 233); Plac. philos. 1.3.21.

54 Dillon 1993a, 93.
} 
term $i \delta \varepsilon \dot{\varepsilon} \alpha$ in Pseudo-Timaeus designates the sum total of the forms. ${ }^{55}$ What is important for the present discussion is that this unified form is elsewhere referred to as sixwiv. ${ }^{56}$ The following passage is a good illustration of this use of the term:

After the establishment of the world, he [i.e., the demiurge] began to plan the generation of mortal living beings, so that the world would be made complete in every way in relationship to the image $(\dot{\alpha} \varepsilon i x \dot{\omega} \nu) .{ }^{57}$

Another important source for the Middle Platonist use of the term six $\omega$ v is Plutarch. According to his Plat. quaest. $1007 \mathrm{c}-\mathrm{d}$, time and the world are two

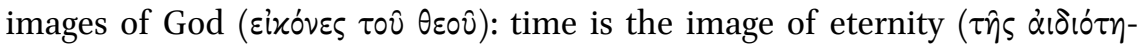

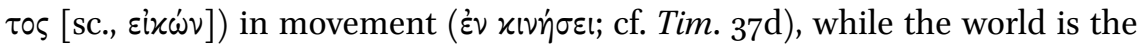

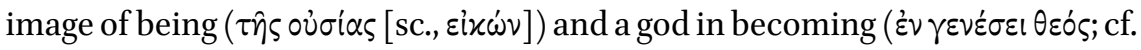
Tim. 92c). A similar statement occurs in Is. Os. $372 \mathrm{f}$, where Plutarch argues that "becoming is the image of being in matter and that which comes into being is

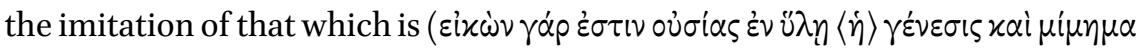
$\tau 0 \hat{~ o ै v \tau o \varsigma ~ \tau o ̀ ~ \gamma(v o ́ ~} \mu \varepsilon v 0 v) .{ }^{n 8}$ Interestingly, the last notion is repeated almost ver-

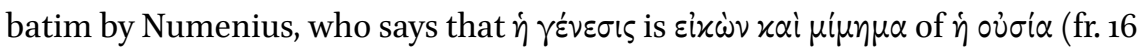
des Places = Eusebius, Praep. ev. 11.22.3).

At the same time, Plutarch is familiar with paradigmatic images. In Quaestiones convivales, Tyndares argues that, according to Plato, geometry draws us away from the sensible realm and turns us towards the intelligible one. This is why Plato opposed the geometricians, who use mechanical devices instead of reason: ${ }^{59}$ because of that, geometry falls back on sensible objects and no longer

55 Cf. Baltes 1972, 35; according to Tobin 1985, 16, the form in Pseudo-Timaeus becomes the intermediate figure between God and matter.

56 Cf. Baltes 1972, 136.

57 Nat. mund. an. 43, trans. T.H. Tobin.

$5^{8}$ The Greek text is from Bernardakis 1888-1896, 2:528, who accepted the emendation of Johann Jakob Reiske. Following the suggestion of Jeremiah Markland, most editions (Nachstädt, Sieveking, and Titchener 1971, 54; Griffiths 1970, 53; Froidefond 1988, 226) read

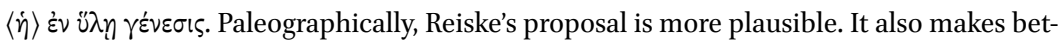
ter sense: according to Plato's Tim. $5^{2 c}$, every image is of something and in something; it is this Platonic pattern that Plutarch follows both in Platonicae quaestiones (when he says that time is the image of eternity in movement, and the world is the image of being in becoming) and in De Iside et Osiride (when he says that becoming is the image of being in matter).

59 For this (historically improbable) anecdote and its possible origins, see Riginos 1976, 145146. 
lays hold of "the eternal and immaterial images in the presence of which God

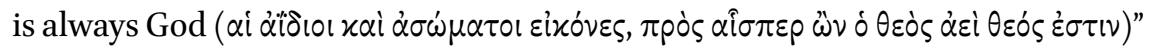
(718f; trans. E.L. Minar). Quite remarkably, the last part of this passage alludes to Phaedrus, where Socrates describes the forms as "those realities by being close to which the gods are divine ( $\pi$ pò A. Nehamas and P. Woodruff). ${ }^{60}$

Apuleius was also aware of the distinction between $\varepsilon i x \omega \dot{\omega} \nu$ as $\mu i \mu \eta \mu \alpha$ and

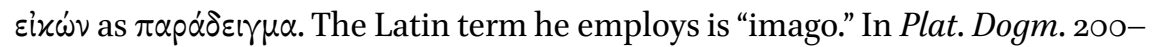
201, he paraphrases Tim. $37 \mathrm{~d}$, saying that "truly, time is an image of eternity, although time moves, while the nature of perpetuity is fixed and immovable (tempus uero aeui esse imaginem, si quidem tempus mouetur, perennitatis fixa et inmota natura est)." A comparison of Plato's text with Apuleius' paraphrase leaves no doubt that Apuleius uses the Latin noun "imago" as an equivalent of

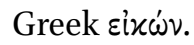

Just like in Plato, "image" here refers to an imitation of a model-i.e., time is an imitation of eternity. Similarly, in his exposition of the doctrine of the two substances, the sensible and intelligible ones, ${ }^{61}$ Apuleius claims that the former is "so to speak, a shadow and an image (ueluti umbra et imago)" of the latter (Plat.Dogm. 194). In other words, the sensible substance is an imitation of the intelligible one. There is one passage, however, where "image" is a synonym of "model":

'I $\delta$ źas uero, id est formas omnium, simplices et aeternas esse nec corporales tamen; esse autem ex his, quae deus sumpserit, exempla rerum quae sunt eruntue; nec posse amplius quam singularum specierum singulas imagines in exemplaribus inueniri gignentiumque omnium, ad instar cerae, formas et figurationes ex illa exemplorum inpressione signari.

Truly, i $\delta \dot{\varepsilon} \alpha$ l, the forms of everything, are simple and eternal, but not corporeal. Those of them, which God chose, are models of the things that either are or will be. It is not possible to find in the models more than particular images of particular species. Forms and shapes of all things that come into being, just like those of wax, are marked by this impression of the models. ${ }^{62}$

\footnotetext{
6o Cf. Teodorsson 1989-1996, 3:167.

61 I discuss this doctrine in chapter 6 (p. 173).

62 Plat. Dogm.192-193.
} 
The last sentence of the cited passage provides us with an additional reason why models may be called "images." Wax is molded by a seal; in a similar fashion, sensible objects of a certain species are molded by a model; ${ }^{63}$ this model is, in turn, the image of this species. Just like impressions in clay or wax are all copies of a single image carved on a seal, so also all images (i.e., mundane objects) are likenesses or imitations of one image, their model. In other words, a model of an image is a paradigmatic image, an image of which other images are likenesses and imitations.

The last Middle Platonist that deserves to be mentioned in this survey is Theon of Smyrna. He is also familiar with the concept of paradigmatic image. According to him, the triad ( $\dot{\eta} \tau p \dot{\alpha} s)$ is the image $(\varepsilon i x(\dot{\omega} v)$ —i.e., the model—of the plane (Util. math. 100.21-22 Hiller), while the tetrad ( $\dot{\eta} \tau \varepsilon \tau p \alpha \dot{\varsigma})$ is the image ( $(\dot{i x} \omega \dot{\omega} v)$ of the solid (101.11 Hiller).

As the following passage demonstrates, Theon was also aware of the concept of the mundane image. In fact, the last sentence of this passage provides us with one of the most articulate and concise definitions of the relationship between the intelligible and sensible realms: $\tau \dot{\alpha} \alpha i \sigma \theta \eta \tau \dot{\alpha}$ are the images of $\tau \dot{\alpha}$ von $\tau \dot{\alpha}$. Theon's point is that nobody can be a philosopher without imitating the forms - that is, without making his life the image of the intelligible realm (the implicit premise of this argument is that like is known by like):

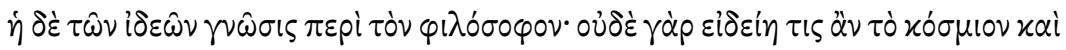

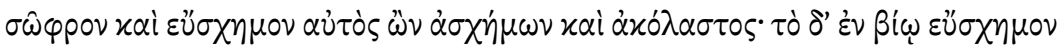

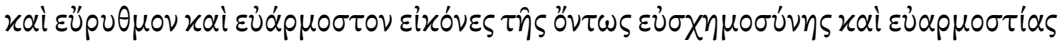

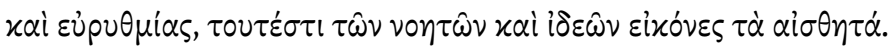

Philosophers ought to seek the knowledge of the forms. Should one be indecent and incontinent, one would not be able to learn that which is well-ordered, reasonable, and noble. The things that are noble, wellproportioned, and harmonious in our life are the images of true nobility, harmony, and proportion. That is to say, the sensible objects are the images of the intelligible objects and forms. ${ }^{64}$

63 For other instances of models compared to seals, see, e.g., the passage from Alcinous quoted above (p. 232) and the parallel material in Arius Didymus; cf. Philo, Opif. 129. This metaphor goes back to Tim. 5 oc.

64 Util. math. 12.4-9 Hiller. 
It is now time to draw the conclusions. According to saying 83, there are two types of images: the mundane and the divine. The mundane ones are manifest, the divine ones, as we learn from Gos. Thom. 84:2 (see the discussion below, pp. 251-253), are immortal and hidden. This contrast between the two types of images is very similar to the one attested in Platonism. According to several Middle Platonists, there are mundane images and there are paradigmatic ones. Sensible objects are transitory, because they are mere images of their eternal and intelligible models, yet these eternal and intelligible models are also often called images. Not only are these two different meanings of "image" attested in Middle Platonism; as we have seen, both types of images are often mentioned by the same author and even in the same text. ${ }^{65}$ In view of this remarkable terminological similarity, it seems reasonable to suggest that both the phrasing and metaphysics of saying 83 are indebted to Middle Platonism.

\section{Eixc่v $\theta \varepsilon \odot \hat{v}$ as a Paradigmatic Image}

There is, however, an important detail that deserves to be discussed at lengthviz., that the paradigmatic image of Gos. Thom. 83:2 is the image of the father. To be sure, it is grammatically possible for Teq2ik WN in Gos. Thom. 83:2 to refer to поүоєाn as opposed to пеіют. Yet "the image of the light of the father" is quite an obscure expression; it was the incomprehensibility of this expression that forced scholars to emend the text in the first place.

"Father" is the regular name of the true deity in the Gospel of Thomas, and it seems quite natural to suggest that "the image of the father" refers to the Genesis narrative about the creation of the humankind $x \alpha \tau^{\prime}$ eixóv $\alpha$ $\theta \varepsilon \circ \hat{v}$ (Gen 1:2627). ${ }^{66}$ Hence, it is reasonable to surmise that the Gospel of Thomas belongs to the tradition of the Platonizing exegesis of Gen 1:26-27 and interprets $\varepsilon i x \omega \nu$ $\theta \varepsilon \circ 0$ as a paradigmatic image, the model, of which humans are imitations. Notably, this interpretation is not unknown in Middle Platonism. In what follows, I discuss Philo and Clement, who were left out of the previous section precisely because of their metaphysics of $\operatorname{six} \dot{\omega} \nu \theta \varepsilon \circ \hat{v}$.

65 See the discussion of Pseudo-Timaeus, Plutarch, Apuleius, and Theon, above; see also the discussion Philo and Clement, below.

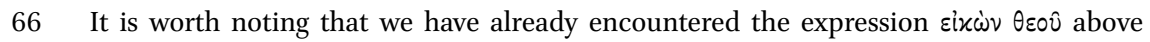
(p. 236): according to Plutarch, time and the world are God's images. This particular passage, however, is hardly relevant for the interpretation of Gos. Thom. 83:2, since both time and the world are mundane images and, therefore, belong to N21кWN of Gos. Thom. 83:1. 
Let us start with Philo. Like the majority of Platonists discussed in the previous section, he is familiar with the concept of mundane image. It is worth noting that, in addition to $\varepsilon i x \omega \dot{v} v$, Philo uses the term $\dot{\alpha} \pi \varepsilon \mid x o ́ v i \sigma \mu \alpha$, yet there seems to be no terminological difference between these two words (see, e.g., Her. 231, where they are used interchangeably). In Mos. 2.127, he argues that

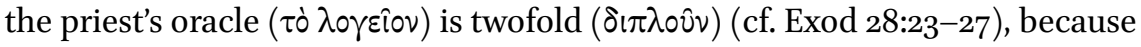

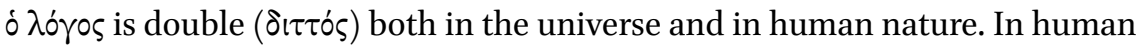

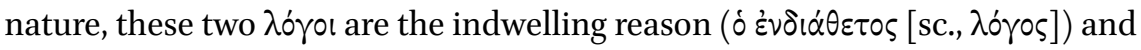

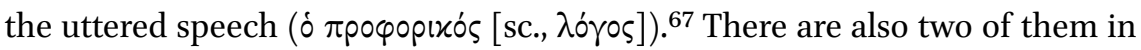
the universe: first, there is the principle that deals with "the incorporeal and

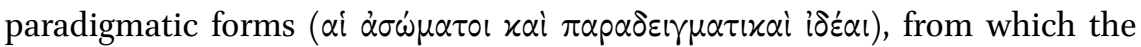
intelligible world was framed." Second, there is the principle that deals with "the visible objects ( $\tau \dot{\alpha}$ óp$\alpha \tau \dot{\alpha})$ which are the imitations and images $(\mu \mu \eta \dot{\eta} \mu \alpha \tau \alpha$

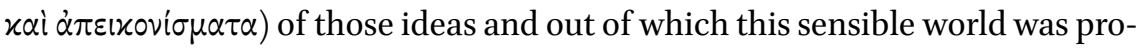
duced" (trans. F.H. Colson, altered). When Philo describes the creation of the visible world, he similarly describes it as an image and imitation of the intelligible one:

For God, being God, assumed that a beautiful copy $(\mu i \mu \eta \mu \alpha)$ would never be produced apart from a beautiful pattern $(\pi \alpha p \alpha \dot{\delta \varepsilon} \gamma \mu \alpha)$, and that no object of perception would be faultless which was not made in the likeness of an original discerned only by the intellect (oن่ $\delta \dot{\varepsilon} \tau \iota \tau \hat{\omega} \nu \alpha i \sigma \theta \eta \tau \hat{\omega} \nu$

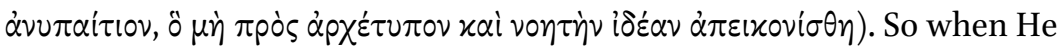
willed to create this visible world He first fully formed the intelligible world, in order that He might have the use of a pattern wholly God-like and incorporeal in producing the material world, as a later creation, the very image ( $\dot{\alpha} \pi \varepsilon i \dot{o}^{\prime}(\sigma \mu \alpha)$ of an earlier, to embrace in itself objects of perception of as many kinds as the other contained objects of intelligence. ${ }^{68}$

This meaning of $\varepsilon i x \omega$ is is also attested in those Philonic works that are preserved only in Armenian. The Armenian word that corresponds to Greek six is पtinumunui. Admittedly, this Armenian word is polysemantic ${ }^{69}$ and, according to the New Dictionary of the Armenian Language, might render various

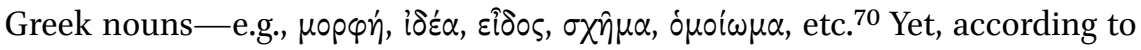

\footnotetext{
67 This distinction comes from Stoicism; see $S V F$ 2.135.

68 Opif. 16, trans. F.H. Colson and G.H. Whitaker.

69 See Bedrossian 1985, 343 .

70 See Awetik'ean, Siwrmēlean, and Awgerean 1836-1837, 1:1092.
} 
Ralph Marcus' Index, when it comes to Philo's Quaestiones, there seems to be one-to-one correspondence between Lடnumunui of the Armenian translation and $\varepsilon i x \omega \dot{v}$ of the Greek original, judging from the surviving Greek fragments. ${ }^{71}$ Hence, there is no reason to doubt that in $Q G$ 4.115, Ltрuшumuip renders

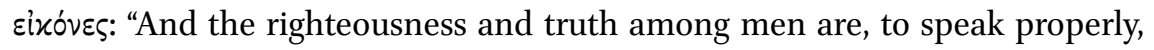
likenesses and images (4tinumumup), while those with God are paradigmatic principles and types and ideas" (trans. R. Marcus). ${ }^{72}$ Thus, just like the sensible world is the image of the intelligible one, so also is human righteousness in the image of the divine one. ${ }^{73}$

On the other hand, it is in Philo that the term sixw'v in the sense of "model" appears for the first time, though it is unlikely that it was Philo who introduced this new meaning. ${ }^{74}$ The most remarkable example is Somn. 1.79 , where he claims that we turn to sense-perception, "when we are no longer able to remain in company with holiest forms ( $\alpha i$ i $\varepsilon \rho \omega \dot{\omega} \tau \alpha \tau \alpha l i \delta \varepsilon \dot{\varepsilon} \alpha)$, which are as it were incor-

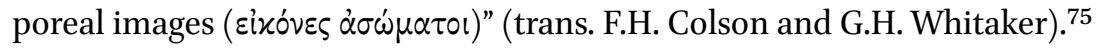

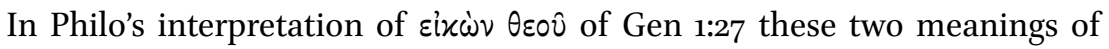

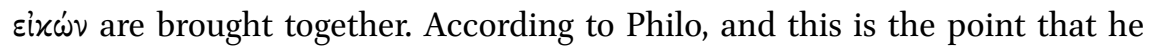
repeats again and again, the image of God is his Logos. ${ }^{76}$ This image of God is at the same time the model of all creation, including humanity. "Just like God is the model for the image (

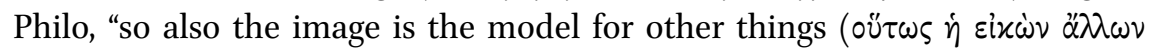

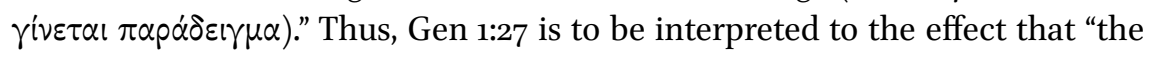
image was modeled according to $\operatorname{God}(\varkappa \alpha \tau \dot{\alpha} \tau \dot{o} \nu \theta \varepsilon \dot{\nu} \nu \dot{\alpha} \pi \varepsilon เ x \circ v i \sigma \theta \varepsilon \hat{\sigma} \sigma \alpha)$, while the

$71 \quad$ Marcus 1933, 268; see $Q G$ 2.62; 4.110 (not listed by Marcus); $Q E$ 2.66. Admittedly, in the Armenian translation of De vita contemplativa, पடрuшиui translates $\sigma \times \hat{\eta} \mu \alpha$ (Contempl. 51) and $\varepsilon^{\prime} \delta \omega \lambda$ ov (Contempl. 72).

72 There are two other passages in the Armenian Quaestiones where पtumunuip seems to render sixóves in the sense of mundane images: $Q G 1.54$ and $Q E 2.58$.

73 It is worth noting that the other meaning of $\varepsilon i x \dot{\omega} v$, that of the paradigmatic image, seems to be also attested in the Philonic works preserved only in Armenian: see Anim. 29 and 95,

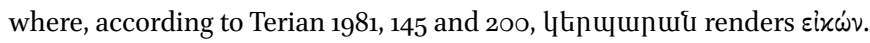

74 Cf. Theiler 1970, 499. Willms 1935, 29-30, and Baltes 1972, 21-22, assume that this meaning originated from the circle of Antiochus of Ascalon, an etiology which, as Tobin 1985, 25, notes, is by no means certain.

75 According to Willms 1935, 76-77, Philo finds grounds for treating the terms i $i \delta \varepsilon \alpha$ and $\varepsilon \dot{i} x \dot{\omega} \nu$ as synonyms in Gen 5:3.

76 See, e.g., Spec. 1.81; Somn. 1.239; Fug. 101; Conf. 97; 147. It should be noted, however, that sometimes Philo offers alternative interpretations of the $\varepsilon i x \dot{\omega} \nu$ $\theta \varepsilon 0 \hat{v}$ of Gen 1:27; see Sterling $2013,47-56$. 


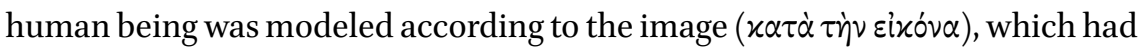
acquired the force of a model" (Leg. 3.96).

While the Pentateuch says that only the human being was created according to God's image, Philo is confident that the same holds true for the sensible realm in toto. He gives reasons for this claim in Opif. 25. In this passage, as Gregory E. Sterling points out, ${ }^{77}$ the Alexandrian offers an argumentum a minore ad maius: if humanity is a part of the world and was created according to God's image, then the world was also created according to God's image:

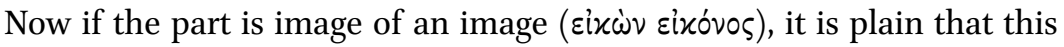
is also the case for the whole. But if this entire sense-perceptible cosmos, which is greater than the human image, is a representation of the divine image ( $\mu$ í $\eta \mu \alpha \theta$ gís sixóvos), it is plain that the archetypal seal, which we

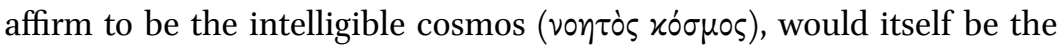

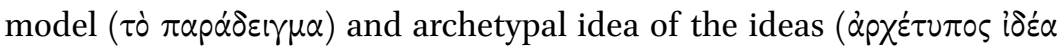

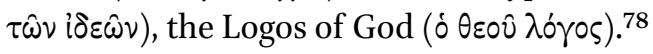

As Sterling puts it, "Philo has a three-tiered hierarchy: God, the Logos, and humanity." ${ }^{79}$ In this hierarchy, Logos is the mediator and therefore plays a dual role: it is both an imitation and a model. Thus, when, in Somn. 2.45, Philo says that God sealed ( $\dot{\sigma} \sigma \rho \rho \alpha$ ' $\gamma(\sigma \varepsilon)$ the universe "with the image and form-i.e., with

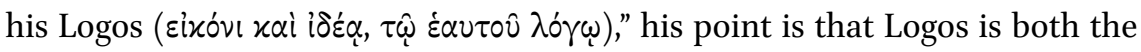
image (= imitation) of God and the form (= model) of the universe. ${ }^{80}$ This is also the reason why God is at the same time the model of the image ( $\pi \alpha \alpha_{\alpha} \delta \varepsilon l-$

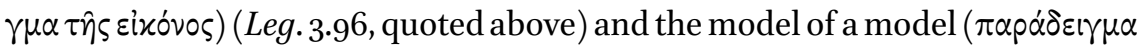
$\langle\pi \alpha p \alpha \delta \varepsilon i \gamma \mu \alpha \tau \circ \varsigma)\left(\right.$ Somn. 1.75). ${ }^{81}$

In Her. 230-231, Philo insists that it is crucial that, according to Gen 1:27, God did not make man his image, but rather after his image. The image is the Logos, and the man that was created according to the image is "the mind in each of us"

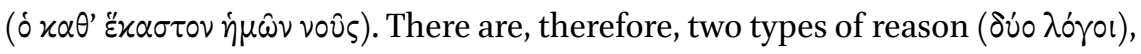

\footnotetext{
77 See Sterling 2013,45 .

78 Opif. 25 , trans. D.T. Runia. The translation departs from Cohn's text and follows the readings suggested in Runia 2001, 94.

79 Sterling 2013, 45 .

8 C Cf. Colson et al. 1929-1962, 5:6o7; Runia 1986, 163.

81 This conjecture was suggested in Colson et al. 1929-1962, 5:336, and accepted by Sterling $2005,132$.
} 
the archetypal reason above us and its imitation within us. Philo concludes that

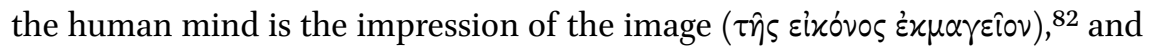

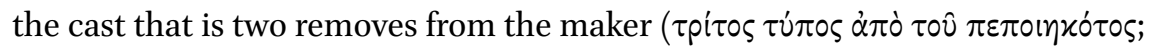
cf. Plato, Resp. 597e; cf. also Clement, Strom. 7.3.16.6), while Logos is the middle cast ( $\delta \mu \varepsilon \dot{\sigma} \sigma \varsigma$ [sc., $\tau \dot{\tau} \pi \circ \varsigma$ ]) that is the model of the human mind and the image

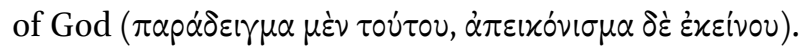

Interestingly, Philo also addresses the fact that man was made not only after the image, but also after the likeness (Gen 1:26). In Opif. 71 , he notes that not all the images resemble their models, but, in fact, many are dissimilar ( $\left.\alpha v^{\prime} \mu 0101\right) .{ }^{83}$ Since this has nothing to do with divine creation, Moses added "after the likeness" ( $\kappa \alpha \theta^{\prime}$ ' $\left.\mu \sigma^{\prime} \omega \sigma \nu\right)$ in order to emphasize that, in this case, we are dealing

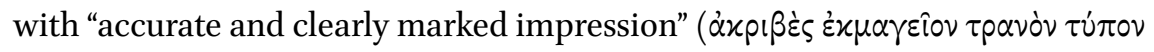
है $\chi \omega \nu)$.

It has already been pointed out that a model may be called the image of an object in so far as the former acts as some sort of blueprint for the latter. Moreover, I have suggested that a comparison of models with seals may also shed some light on this use of the term "image": models are like the images on the seals that are imitated by their impressions in wax or clay. Philo provides us with yet another explanation: some models are images, because they have their own models; sometimes, there is a model of which this model is an image. Thus, the supreme model is the model of the lower model, the lower model is the image of the supreme model, and the images of the lower model are images of the image.

It is now time to turn to Clement. Although the notion of the mundane image does not play an important role in his writings, he is nevertheless familiar with it. According to Strom. 5.14.93.4, the barbarian philosophy-i.e., the Bible-is aware of the fact that the visible universe is the image and imitation of the noetic one. According to Salvatore R.C. Lilla, this is one of those instances where Philo is Clement's "teacher and model": ${ }^{4}$

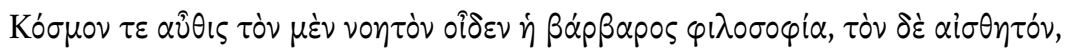

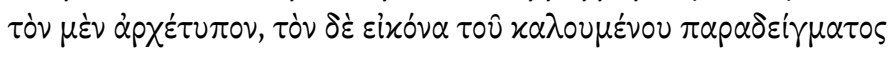

\footnotetext{
82 Philo likens the paradigmatic image (= Logos) to the seal, and the imitations of the image (= human minds) to the impressions of the seal. Cf. the discussion of this imagery in Apuleius, above (p. 238).

83 This notion is reminiscent of Plato's discussion of poorly and finely made images (Crat. 431c-e; see above, p. 227).

84 See Lilla 1971, 191-192.
} 
Moreover, the barbarian philosophy knows that there is the intelligible world and the sensible one and that the former is the archetype and the latter is the image of the so-called model.

It is, however, more important for the present discussion that Clement follows Philo in his interpretation of Gen 1:26-27.

Like Philo, Clement argues that the image of God is God's Logos, whom he identifies with the Son, and that the man made after this image (= the image of the image) is the human mind: "the image is God's divine and royal Logos, the human being that is free from passions, and the image of the image is the

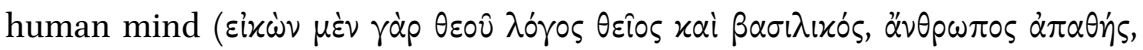

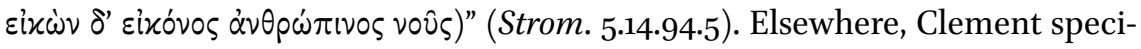
fies that the common element in this threefold hierarchy of God, his Logos, and humanity is the mind: the human mind is the image of Logos, who is the son of the mind (= God). ${ }^{85}$ Notably, Philo offers a very similar hierarchy of minds in Her. 230-231 (see the discussion above).

For "the image of God" is His Logos (and the divine Logos, the light who is

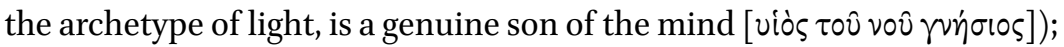
and the image of Logos is the true man, that is, the mind in man ( $\delta$ vov̂s $\dot{\delta} \dot{\varepsilon} \nu \dot{\alpha} \nu \theta \rho \dot{\omega} \pi \omega)$, who on this account is said to have been created "after the image" of God, and "after the likeness," because through his understanding heart he is made after the image ( $\left.\pi \alpha p \varepsilon \mid x \alpha \zeta \zeta^{\prime} \mu \varepsilon v o \varsigma\right)$ of the divine Logos, and so reasonable $\left(\lambda \circ \gamma_{\text {ixós }}\right) .{ }^{86}$

There is, however, a remarkable innovation that Clement makes in his interpretation of Gen 1:26-27.

Unlike Philo, Clement interprets $x \alpha \theta^{\prime} \delta \mu o i \omega \sigma \nu$ of Gen 1:26 from the standpoint of the Platonist doctrine of the goal of human life-i.e., $\delta \mu o i \omega \sigma \iota \varsigma, \theta \varepsilon \hat{\omega}$

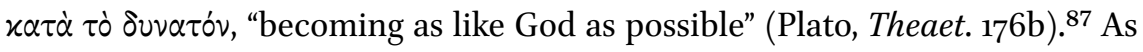

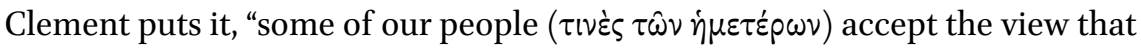
a human being has received 'according to the image' at birth, but will secure 'according to the likeness' later, as he attains perfection" (Strom. 2.22.131.6; trans. J. Ferguson). That, by "some of our people," Clement refers to himself is clear from the following exhortation, which Clement puts in the Son's mouth (Protr. 12.120.4).

\footnotetext{
85 Cf. Casey 1924, 46.

86 Protr. 10.98.4, trans. G.W. Butterworth, altered.

87 Cf. Runia 2001, 233.
} 


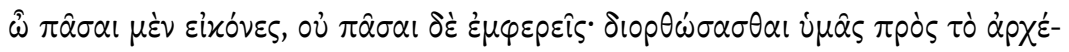

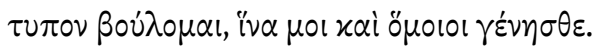

All of you are images, but not all of you resemble your archetype; I want to restore you to order, so that you may become like me.

In his interpretation of $\varkappa \alpha \theta^{\prime} \dot{\delta} \mu o^{\prime} \omega \sigma i v$, Clement starts from the same premise as Philo did: not all images faithfully imitate their models. Yet the conclusions they

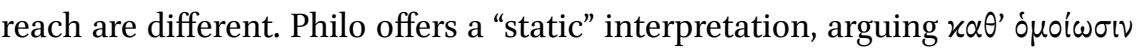
is added to $x \alpha \tau^{\prime}$ cixóv $\alpha$ precisely in order to emphasize that Gen 1:26-27 refers to images that accurately resemble Logos. Clement, on the other hand, offers a "dynamic" interpretation, claiming that human beings are imperfect images of Logos and that their goal is to set themselves right and to become like their model.

This survey of the Platonizing interpretations of Gen 1:26-27 allows me to take a step forward in the interpretation of saying 83 . Since this saying is familiar with the Platonist dialectic of mundane and paradigmatic images and since this saying also alludes to the Biblical concept of God's image, it seems reasonable to conclude that the Gospel of Thomas shares its understanding of Gen 1:26-27 with Philo and Clement and interprets $\varepsilon i x \omega \dot{\omega} \nu \theta \varepsilon 0 \hat{v}$ as the paradigmatic image after which humanity was created.

\section{The Meaning of Gos. Thom. 83:1}

It is now possible to proceed to the interpretation of saying 83 . The structure of the saying is antithetic; its two parts are set against each other, the first dealing with the mundane images, the second with the paradigmatic images. I begin with the first part. Gos. Thom. 83:1 consists of three statements: (i) there are images that are manifest to the humankind (there can be little doubt that прФме is used in the collective sense; cf. the discussion of өाкळN below); (ii) there is light within these images; (iii) this light is concealed "in the image." Let us discuss these statements one by one.

(i) First of all, it seems reasonable to suggest that Gos. Thom. 83:1 makes use of the Platonist metaphysical vocabulary and employs the term N2IKON ( $\left.{ }^{*} \varepsilon i x o ́ v \varepsilon \varsigma\right)$ in the sense of the sensible (mundane) objects. ${ }^{88}$ As my survey 
has shown, this meaning of $\varepsilon i x \omega \dot{v} v$ originated with Plato and is attested in various Middle Platonists, including Philo, Pseudo-Timaeus, Plutarch, Alcinous, Apuleius, Numenius, Theon, and Clement.

(ii) Second, the idea that there is light within the mundane objects would not be confusing for the readers of the Gospel of Thomas. The Gospel of Thomas calls the ultimate reality that everyone has to look for "the light" and "the kingdom" (cf., e.g., sayings 49 and $5^{\circ}$ ) and a number of Thomasine sayings teach that the kingdom/the light is already present in the world, yet no one can see it. ${ }^{89}$

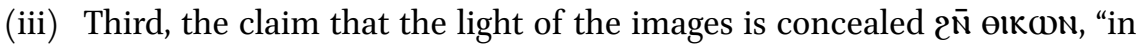
the image," is somewhat problematic. The antithetic structure of saying 83 suggests that Gos. Thom. 83:1 and 83:2 are supposed to mirror each other: if, according to Gos. Thom. 83:2, the image of the father is concealed by the light, then, according to Gos. Thom. 83:1, the light must be concealed by the images. The problem, however, is that the light is said to be con-

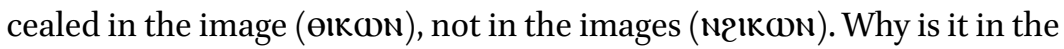
singular and not in the plural?

It is possible that өIKWN refers to the world. As my survey has shown, the world is qualified as an image in Plato, Philo, Pseudo-Timaeus, Plutarch, Alcinous, and Clement. The world can also be called the image, since, as the greatest of all images, it contains in itself all other images.

It is more plausible, however, that the author is merely making a generic point. ${ }^{90}$ It is fairly certain that прФме in Gos. Thom. 83:1 is used in the collective sense and refers to every single human being. Similarly, пєт̄̄eın€ in Gos. Thom. 84:1 (quoted below, p. 251) means "your likeness" in general (i.e., "anything that resembles you"). Thus, it seems reasonable to suggest that the singular number of eikळN is supposed to be understood in the same way. It is also possible that the author wrote elkON, in order to accentuate the antithetic parallelism of the two parts of the saying: the singular number of eiкळN in Gos. Thom. 83:1 matches the singular number of теч21кळN in Gos. Thom. 83:2. Thus, the image that conceals the light is contrasted to the image that is concealed by the light.

89 See the detailed discussion of this Thomasine motif in chapter 2.

9o Stephen J. Patterson pointed this out to me in a personal communication. 


\section{The Meaning of Gos. Thom. 83:2}

While Gos. Thom. 83:1 describes the present situation, Gos. Thom. 83:2 deals with what is going to happen in the future. Gos. Thom. 83:2 states that, in the future, the light of the father will become manifest. The implication of this statement is that the light of the father is not yet manifest in the present. And, if the light of the father is not manifest in the present, there has to be a reason for this. Since the focal point of Gos. Thom. 83:2 is the relationship between the light of the father and the image of the father, it seems reasonable to suggest that the hiddenness of the light of the father in the present is somehow related to the current state of the image of the father.

My suggestion is that the author of saying 83 shares with some other early Christians their belief that humanity had lost their divine image, $\varepsilon i x \dot{\omega} \nu \theta \varepsilon \circ \hat{v}$, after the Fall. ${ }^{91}$ In the present, the light of the father is hidden, because the image of the father is lost; in the future, the divine image will be restored, and this will make the divine light manifest.

The notion of the loss of God's image as a postlapsarian condition is present, for instance, in Tatian's Oratio ad Graecos. According to Tatian, the first human beings had both the soul and something that was greater than the soul, the

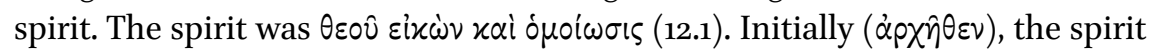
was the soul's companion, but "gave it up when the soul was unwilling to follow it" (13.2; trans. M. Whittaker). This happened because of $\sin (\delta i \dot{\alpha} \tau \dot{\eta} \nu$ d $\mu \alpha \rho \tau i \alpha \nu)$ (20.1). After the transgression, the one who was made in the image of God was separated from the spirit and became mortal (7.3). ${ }^{92}$ Hence, "we ought now to

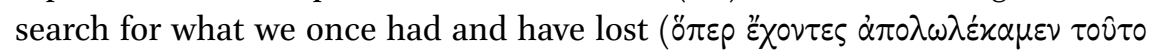

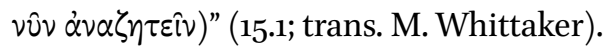

The motif of the lost image of God is present in Gos. Thom. 22:6 and 84:2. As I have argued in chapter 4 (pp. 95-96), the exhortation to make "an image

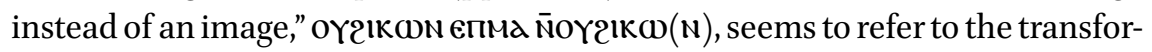
mation of "the image of Adam" (Gen 5:3) into "the image of God" (Gen 1:26-27 and 5:1 LXX). The fact that this transformation is necessary implies that, in the present, humankind is not in possession of the image of God, that the divine image was replaced with another, non-divine image.

The same notion of the loss of God's image seems to be attested in saying 84. This saying (quoted below, p. 251) contrasts the vision of our sensible likenesses (reflections, portraits, statues, etc.) with the vision of our divine images.

91 Cf. DeConick 1996, 157-164.

92 This idea seems to be attested already in Wis 2:23-24. 
The implication seems to be that both likenesses and images exist outside of us. Moreover, according to Gos. Thom. 84:2, they came into being before us, and, unlike us, they will not perish. Most importantly, divine images do not become manifest. Just like the divine light is hidden in Gos. Thom. 83:2, so also are the divine images hidden in Gos. Thom. 84:2. While our likenesses are easily accessible, our images are elusive: they are concealed from us and therefore evade our grasp. Since they are virtually out of our reach, it takes effort to obtain vision of them. When obtained, this vision is hardly bearable. Although saying 84 does not provide us with any explanation why our images are removed from us, it is reasonable to conclude that these images were in us at some point and that we later became separated from them (i.e., lost them).

Thus, Gos. Thom. 83:2 presupposes that the protoplast was in the possession of God's image when he was in paradise and that he was deprived of it after the Fall. The loss of God's image is the reason why the light of the father is hidden. The question remains, however, what exactly does "the light of the father," поүоєाм $\bar{M} п є І ळ т$, mean? Since loss of the divine image is a postlapsarian condition, it seems natural to suggest that the disappearance of the divine light is also a postlapsarian condition. I suggest, therefore, that "the light of the father" refers to the divine light that surrounded Adam before the Fall.

A number of early Jewish texts maintain that, before the Fall, Adam was a luminous being. The absence of visible radiance is thus a postlapsarian condition: it indicates that human nature has become perverted. When human beings restore their nature, they will once again be luminous. As Louis Ginzberg points out, "the splendor of Adam's countenance is the concrete expression of the legend of the divine nature of man before his fall, and belongs to the view concerning the light of the pious in the world to come, which is prevalent in Jewish, as well as in Christian, eschatology." ${ }^{\prime 93}$

Many early Jewish literary texts state that, after the transgression, Adam lost his glory. ${ }^{94}$ According to the Life of Adam and Eve, when Eve ate from the fruit, she realized that she committed a sin and said, "I have been separated from

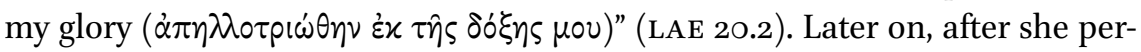
suaded Adam to eat the fruit, he said, "You have separated me from God's glory

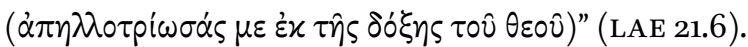

It should be reminded at this point that, in the Hebrew Bible, the glory is quite often understood as a visible radiance (see, e.g., Exod 24:16; 1 Kgs 8:10-11). This is also the case in early Christian literature (Luke 2:9; 9:31-32). It is quite

93 Ginzberg 19o9-1928, 5:112.

94 See, e.g., Rom 3:23 and 3 Bar 4.16. See also the examples listed in Jervell 1960, 45. 
clear that $\delta o ́ \xi \alpha$ is a radiant substance in the Life of Adam and Eve as well. The serpent says to Eve, "come to the plant [i.e., to the tree in the midst of the paradise] and you will see the great glory" (LAE 18.5), which implies that the glory is visible. ${ }^{95}$

The idea that in the last times the righteous ones will restore their glory is also present in early Jewish literature (see, e.g., 1 En. 50.1; cf. Rom 8:17-18). It parallels the idea that the righteous ones will shine like the sun and the stars (see, e.g., Dan 12:3; Matt 13:43; 4 Ezra 7.97, 125; 1 En. 104.2; 2 Bar. 51.10). ${ }^{96}$

According to 2 En. $66.7,{ }^{97}$ the radiance of the righteous will be much brighter

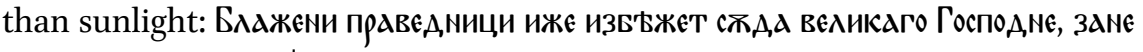

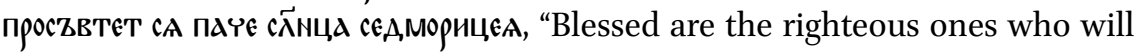
escape the great judgment of the Lord, for they will shine seven times brighter than the sun." 98 In the second century, Montanus, an early Christian teacher, went even further and claimed, "The righteous one will shine a hundred times brighter than the sun" (Epiphanius, Pan. 48.10.3).

95 Moreover, some manuscripts make the luminous nature of glory even more obvious by

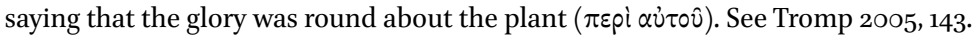

96 Most of these examples are from Bousset and Gressmann 1966, 277; see also Somov 2017, 172-174.

97 The text reproduced below comes from the long recension of 2 Enoch. Verse 66.7 of the long recension is parallel to verse 65.11 of the short recension, Блажєни правєдници ижє

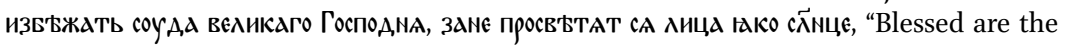
righteous ones who will escape the great judgment of the Lord, for (their) faces will shine like the sun" (Vaillant 1952, 62). It seems that the text of the long recension, with its emphasis on the symbolism of the number seven (see Böttrich 1992, 118), is original, whereas the text of the short recension is a later harmonization with Matt 17:2. It is worth noting that the relationship between the two recensions of 2 Enoch, the long and the short ones, is a matter of debate; see, e.g., Böttrich 2012, 41-44; Navtanovich 2012, 71-77; Macaskill 2013, 19-33. The most balanced position seems to be that of Francis I. Andersen, who argues that, at least in some cases, the manuscripts of the long recension are likely to preserve authentic readings; see Andersen 1983, 93-94; Andersen 2008, 5 .

98 Vaillant 1952, 112. As Böttrich 1996, 10oo, notes, this passage draws on the imagery of Isa 30:26. A similar passage, also dependent on Isa 30:26, occurs in the Thanksgiving Scroll, where the author proclaims, "I shine forth with sevenfold light (באוֹר שבעתים)" (1QHa XV, 27). 2 En. 66.7 also has a number of parallels in early Christian narratives about the Parou-

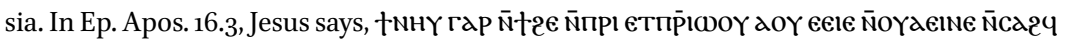
$\overline{\mathrm{N}}$ brighter than it in my glory" (Schmidt 1919, 6*). The same phrase occurs in Apoc. Pet. 1. Cf.

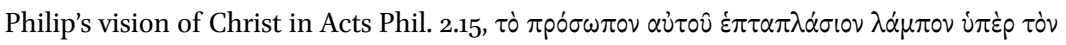

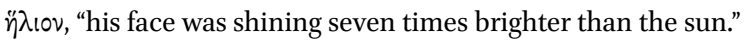


To sum up, Gos. Thom. 83:2 describes the relationship between two entities, the light of the father and the image of the father. This expression, "the image of the father," should be understood as the Thomasine equivalent of sixìv $\theta \varepsilon \circ \hat{v}$ of Gen 1:26-27. The metaphysics of saying 83 is indebted to the Platonizing interpretation of Gen 1:26-27 attested in Philo and Clement. According to this

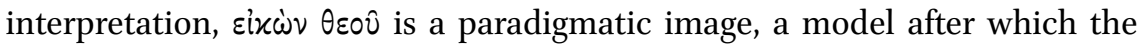
humankind was created.

Interestingly, however, there are certain motifs that Gos. Thom. 83:2 borrowed from non-Platonist sources. First, it adheres to the notion that the image of God was lost. It is because of the loss of God's image that humanity became so miserable. Second, not only did mankind lose the divine image; it also became deprived of its luminosity. It seems that the reason why humans are not luminous at the present time is due to the loss of God's image.

Luckily, the situation is going to change. According to Gos. Thom. 83:2, mankind will regain its divine image, along with which, mankind will also reclaim its luminosity. It is this blinding splendor that Gos. Thom. 83:2 describes, when it notes that the image of the father will be concealed in the light of the father. The point is that the light will be so bright that it will make it impossible to see anything else.

\section{The Metaphysics of the Image in Sayings 22, 50, and 84}

Having discussed the meaning of Gos. Thom. 83, I proceed to other sayings that deal with images-viz., Gos. Thom. 22, 50, and 84. I have already offered an interpretation of the replacement of images in Gos. Thom. 22:6 in the previous section (p. 247). As I have already pointed out, Gos. Thom. 83:2 refers to end times, when the humankind will regain its divine image. Gos. Thom. 22:6 explains how this image was lost and how it can be restored. This saying tells us that some time in the past, the (glorious and divine) image of God was replaced with the (non-divine) image of Adam. To attain salvation means to follow the reverse procedure, replacing the image of Adam with the image of God.

In Gos. Thom. 50:1, when the interrogators ask them where they came from, the addressees of Jesus' instruction are supposed to give the following answer: "We came from the light, the place where the light came into being on its own accord and established [itself] and became manifest through their [read 'our'] ${ }^{99}$ image." In other words, their image was produced by self-generated,

99 See the discussion in chapter 5 (p. 153). 
immovable ${ }^{100}$ light. There seems to be no reason why this image should not be identified with the divine image of Gos. Thom. 22:6 and 83:2, the one that was lost in the past and will be found in the future.

While Gos. Thom. 83:2 deals with eschatology (i.e., the salvific event that will take place in the future), Gos. Thom. 50:1 deals with protology (i.e., the moment that laid the foundation for the history of salvation). There is certainly some similarity between Thomasine eschatology and protology, but the two are by no means identical. Rather, what we have here is antithetic parallelism. In the beginning, the light revealed itself in the image. In the end, the image will be hidden in the light.

Thus, the Thomasine history of salvation presupposes a progress in the dialectic of the image and the light. After light had generated itself and become immovable, it produced the image; it is by means of this image that it became manifest (Gos. Thom. 50:1). When humanity regains its image, the light of the image will be so bright that the light will conceal the image. In other words, the image will produce the light; it is by means of this light that the image will become manifest (Gos. Thom. 83:2). In the past, the image was the manifestation of the light; in the future, the light will be the manifestation of the image.

The last saying to be discussed in this survey is Gos. Thom. 84. Just like Gos. Thom. 83, it offers a fusion of Biblical and Platonist motifs. Certainly, the saying borrows its combination of likeness and image from Gen 1:26, reinterpreting both terms from the Platonist perspective. The Coptic text of Gos. Thom. 84 and its English translation are as follows:

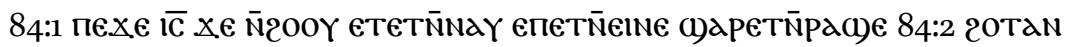

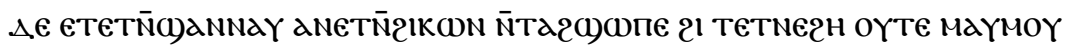
OYTE MAYOYON2 EBOג TETNAYl 2a OYHP

84:1 Jesus said: "When you see your likeness, ${ }^{101}$ you are full of joy. 84:2 But when you will see your images that came into existence before you - they neither die nor become manifest—how much will you bear?"

The phrasing of Gos. Thom. 50:1 (our image) and 84:2 (your images) indicates that both sayings refer to the same phenomenon. ${ }^{102}$ Since sixw'v in Gos. Thom.

100 For the motif of "transcendental" standing in Gos. Thom. 50, see chapter 5.

101 As I have noted above (p. 246), пєт̄̄eınє ("your likeness") in the singular should be understood in the collective sense (i.e., "anything that resembles you").

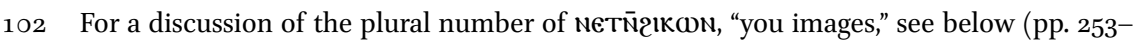
254). 
84:2 designates the same paradigmatic image as it does in sayings 22,50 , and 83 , it follows that the term eive in Gos. Thom. 84:1 is probably also used in the Platonist sense. It probably should be understood as a likeness ( $\delta \mu o i \omega \mu \alpha)$ or an

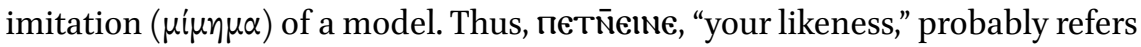
to something like a portrait or a reflection in the water. ${ }^{103}$

It is difficult to ascertain which Greek word, $\delta \mu o i \omega \mu \alpha$ or $\delta \mu o i \omega \sigma \iota \varsigma$, was rendered as eine in Gos. Thom. 84:1. On the one hand, in the Sahidic Bible, eine usually renders Greek o $\mu o i \omega \mu \alpha .{ }^{104}$ On the other hand, in the Sahidic version of

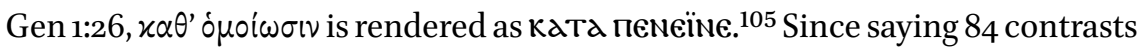
"likeness" with "image" and, therefore, most certainly alludes to Gen 1:26, it is

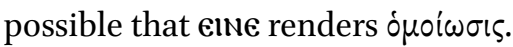

Thus, the author of the saying could have altered the Biblical expression ( $\left.\varepsilon i x \omega^{\prime} \nu+\delta \mu o i \omega \sigma \iota \varsigma\right)$ to the one that sounds more Platonic ( $\left.\varepsilon i x \omega^{\prime} \nu+\delta \mu o i \omega \mu \alpha\right)$. Alternatively, he could have retained the Biblical expression: it is possible that the author did not see any significance in the variation between $\delta \mu o i \omega \mu \alpha$ and o $\mu o$ i$\omega \sigma \mathrm{s}$ and assumed that the two words are synonymous.

That $\delta \mu o i \omega \sigma \varsigma s$ can be used as a synonym of $\delta \mu o i \omega \mu \alpha$ and designate an imitation of a model is clear from the treatise "On Harmony," a third- or secondcentury в В $^{106}$ pseudepigraphon written in Doric and ascribed to Aristaeus of Croton, allegedly a pupil of Pythagoras and his immediate successor as head of the Pythagorean school (Iamblichus, Vit. Pyth. 36.265). Having postulated that the first principle ( $\dot{\alpha} \dot{\alpha} \rho \chi \dot{\alpha})$-i.e., God-is eternal, the author argues that "the images and likenesses of this first principle are both among the things pro-

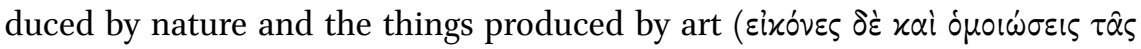

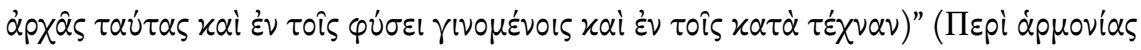
fr. 1 Thesleff = Stobaeus, Anth. 1.20.6).

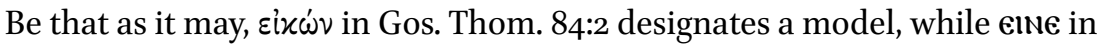
Gos. Thom. 84:1 designates an imitation of a model. The saying, therefore, contrasts the objects that are our imitations with the objects that are our models. Jesus' question may be reformulated in the following fashion: "If you rejoice when you see the things of which you are models, what will happen to you when you see the things that were the models according to which you were made?" In other words, the joy of those who see their mundane likenesses is nothing compared to the reverent awe of those who see their paradigmatic images.

\footnotetext{
103 Cf. Patterson 2013, 47.

104 See Crum 1939, 8ob; Wilmet 1957-1959, 1:195; Draguet 196o, $131 \mathrm{.}$.

105 See Lemm 1906, o98.

106 For this date, see Thesleff 1961, 101-102.
} 
The list of qualities attributed to images also seems to emphasize the distinctiveness of paradigmatic images. According to Gos. Thom. 84:2, the images came into being before humans; moreover, they do not die. Thus, while humans and their likenesses are transitory and perishable, images are primeval and immortal. It is also said that images do not become manifest. Thus, unlike humans and their likenesses, images are hidden. While our likenesses readily present themselves, the images are concealed from us and, therefore, difficult to grasp. Thus, Jesus' question can also be reformulated as follows: "If you rejoice when you see the things that are ephemeral, what will happen to you when you see the things that are indestructible? If you rejoice when you see the things that are manifest, what will happen to you when you see the things that are hidden?"

This last detail, that the images are hidden, is most certainly an indication of their salvific role: the hidden things, after all, are those that Jesus reveals to the ones who become like him (saying 108). The hiddenness of images makes Gos. Thom. 84:2 resonate with Gos. Thom. $50: 1$ and 83:2. According to these sayings, the light and the image play the major role in the salvation history; this salvation history is conceptualized as the dialectic of being hidden and being manifest. According to Gos. Thom. 5o:1, the light became manifest through the image. According to Gos. Thom. 84:2, images do not become manifest. According to Gos. Thom. 83:2, the light that will conceal the image will become manifest.

It seems appropriate to summarize the tenets of the Thomasine metaphysics of image, which, as I have pointed out, is a constituent of the Thomasine salvation history. The salvation history comprises three defining points: the beginning, the Fall, and the final restoration. In the beginning, the light produced itself, established itself ("stood"-i.e., became immovable) and revealed itself through the paradigmatic image. This is the image after which humanity was made (hence, "our" image in Gos. Thom. 50:1). Then, the catastrophic event took place: the divine image was replaced with a counterfeit. Hence, the misery of the present-day world: our images do not reveal themselves (Gos. Thom. 84:2), and the light is concealed in mundane images-i.e., sensible objects (Gos. Thom. 83:1). This situation will change only when we replace the counterfeit image with the true one (Gos. Thom. 22:6). Then and only then will the final restoration take place: humanity will regain its paradigmatic image; the divine light surrounding the image will be revealed; this light will be so bright that no one will be able to see the image (Gos. Thom. 83:2).

The last issue that I must address in this chapter is the seemingly inconsistent use of the singular and plural forms. When Gos. Thom. 84:2 describes the current state of affairs, it refers to divine images, in the plural. Thus, not only are 
the images hidden, they are also not one, but many. All other sayings, however, deal with the divine image, in the singular. Why is this so? It seems reasonable to conjecture that this alternation of the singular number with the plural has something to do with the Thomasine metaphysics of oneness. ${ }^{107}$ The Thomasine salvation history is not only about the lost and regained divine image; it is also about the lost and regained oneness.

As I noted in chapter 4, a number of Thomasine sayings are indebted to the Platonist idea of oneness as perfection. Humanity lacks oneness, and the Thomasine Jesus, much like Middle Platonists, exhorts the reader to "become one." Moreover, just like the Thomasine metaphysics of image is a creative fusion of Platonist and Biblical motifs, so also is the Thomasine metaphysics of oneness. A number of Thomasine sayings (see especially Gos. Thom. 11:4) are likely to presuppose a myth of Adam's initial oneness. Once again, the Gospel of Thomas offers us a tripartite scheme: mankind was one in the beginning; it is devoid of oneness now; and it will regain its oneness in the future.

Once we compare the "history" of oneness and that of the image, it becomes clear why the image was one in the beginning and will be one in the end, and why it is not one now. The fact that "our" images are many (Gos. Thom. 84:2) indicates that, at the present day, humanity lacks oneness and therefore suffers from imperfection. Once we attain perfection and become one, the divine image will also be one, just as it was one in the beginning.

\section{Conclusions}

I began this chapter with a discussion of the text of Gos. Thom. 83. NHC II is our sole witness for the text of this saying. As a rule, the text of the manuscript, as long as it is grammatical, should be accepted as it stands. Yet Gos. Thom. 83 appears to be an exception to this rule. The expression "the image of the light of the father" is bizarre and does not seem to have any parallels in ancient literature, whereas a small and elegant emendation suggested by the Berliner Arbeitskreis makes the saying comprehensible and draws out its resonance with various Greco-Roman and early Jewish traditions. Moreover, the same emendation transforms the saying into a chiasm, one of the frequently-used literary devices in the Gospel of Thomas.

In my discussion of the background of saying 83 , I pointed out that the only intellectual tradition that, just like the Gospel of Thomas, makes a distinc-

107 For a detailed analysis of this Thomasine motif, see chapter 4. 
tion between two types of images, the mundane and divine ones, is Platonism. While Plato uses the term $\varepsilon i x \omega \dot{v} v$, "image," only in the former sense (i.e., as a designation of the sensible objects), Middle Platonists since Philo's times use this term also as a synonym of $\pi \alpha p \alpha \dot{\delta \varepsilon} \varepsilon \gamma \mu \alpha$, "model." Moreover, at least two authors of a Platonist persuasion, Philo and Clement, interpret the creation account in Genesis along the lines of the Platonist metaphysics of the image and thus argue that God's image, after which humanity was made, was in fact the paradigmatic image.

Having discussed the background of saying 83 , I proceeded to its interpretation. The first verse of the saying, Gos. Thom. 83:1 describes our existence in the present-day world. The visible images manifest to us are images in Plato's sense (i.e., sensible objects). There is light in these images, but we cannot see it. The second verse, Gos. Thom. 83:2, describes the moment in the future when the situation will drastically change. Today, we cannot see the light inside the sensible objects. In the future, humanity will regain its divine light-i.e., the splendor that once surrounded the protoplast — and this light will be visible. Humanity will also have restored to it its divine image - -i.e., the image according to which the protoplast was made-but, unlike the mundane images of Gos. Thom. 83:1, this image will be invisible because of the brightness of the divine light.

These findings allowed me to gain better insight into other sayings that deal with images. As I pointed out, Gos. Thom. 50:1 deals with protology (i.e., how the paradigmatic image came about). Gos. Thom. 22:6, on the other hand, deals with the tragic moment in the past, when the paradigmatic image, the image of God (Gen 1:26-27 and 5:1 LXX), was replaced with a counterfeit, the image of Adam (Gen 5:3). To attain salvation means to undo this process and to regain the divine image. Gos. Thom. 84:2 deals with the current state of affairs: it describes the relationship between our images and us in the present.

It is worth noting that, just like saying 83 seems to draw on Platonist speculations about mundane and paradigmatic images, so also does saying 84 appear to be aware of the Platonist notions of the likeness and the model. The "likeness" of Gos. Thom. 84:1 is what Plato called ónoíw $\mu \alpha$ in his dialogues: an imitation of a model-e.g., a reflection in the water or a portrait made by an artist. The "image" of Gos. Thom. 84:2 is the model (i.e., the paradigmatic image). Thus, Gos. Thom. 84:1 describes that which imitates us, whereas Gos. Thom. 84:2 describes that which we imitate. In other words, saying 84 portrays the contrast between different levels of being. Just as a human is greater than his or her likeness, so also is the paradigmatic image of this human greater than the human him- or herself.

Having treated each of the relevant sayings individually, I proceeded to a discussion of the Thomasine metaphysics of the image as a whole. Most signif- 
icantly, the Gospel of Thomas employs the language of the image to talk about salvation history. The sayings discussed in this chapter provide us with sufficient information to reconstruct the Thomasine views on the three defining points in history (the beginning, the Fall, and the end) and the three historical stages (the past, the present, and the future), represented thus:

\begin{tabular}{|c|c|c|c|}
\hline & the past & the present & the future \\
\hline the beginning & & & \\
\hline Gos. Thom. 50:1 & Gos. Thom. 22:6 & $\begin{array}{l}\text { Gos. Thom. 83:1 } \\
\text { Gos. Thom. 84:2 }\end{array}$ & Gos. Thom. 83:2 \\
\hline
\end{tabular}

In the beginning, the light revealed itself by means of the paradigmatic image (Gos. Thom. 5o:1). Later, this image was replaced with a counterfeit (Gos. Thom. 22:6), which is the reason why, today, the light is concealed in mundane images (Gos. Thom. 83:1) and the paradigmatic images do not become manifest (Gos. Thom. 84:2). In the end, the situation will change: the restored image will reveal itself by means of the light (Gos. Thom. 83:2). As this summary demonstrates, Thomasine protology and eschatology do not duplicate each other; the Gospel of Thomas does not envision salvation as merely returning to the original state. Rather, there is an antithetic parallelism between protology and eschatology; the end is, in a way, the opposite of the beginning.

Finally, at the end of this chapter, I offered a reflection on the alternation between the singular and plural numbers in the sayings that deal with the paradigmatic image. The fact that the plural form occurs only in Gos. Thom. $84: 2$, the saying that deals with the current state of events, makes it likely that the use of the plural number is intentional. As I pointed out, to attain salvation in the Gospel of Thomas means not only to restore the image, but also to "become one." Moreover, just like we had the image, but lost it, so also we were "one," but then became "many." Thus, "our images" in the plural in Gos. Thom. $84: 2$ reflects the woeful fact that present-day humanity is devoid of oneness. 